OPEN ACCESS

Edited by:

Lyndy Joy McGaw,

University of Pretoria, South Africa

Reviewed by:

Simone Carradori, Dipartimento di Farmacia, Università "G. d'Annunzio" di Chieti-Pescara,

llana Kolodkin-Gal,

Italy

Weizmann Institute of Science, Israel

Fohad Mabood Husain

King Saud University, Saudi Arabia

*Correspondence: Cassandra L. Quave cquave@emory.edu

Specialty section: This article was submitted to Ethnopharmacology, a section of the journal Frontiers in Pharmacology

Received: 26 April 2018

Accepted: 09 July 2018

Published: 02 August 2018

Citation:

Khan MF, Tang H, Lyles JT, Pineau R, Mashwani Z and Quave CL (2018)

Antibacterial Properties of Medicinal Plants From Pakistan Against Multidrug-Resistant ESKAPE

Pathogens. Front. Pharmacol. 9:815. doi: 10.3389/fphar.2018.00815

\section{Antibacterial Properties of Medicinal Plants From Pakistan Against Multidrug-Resistant ESKAPE Pathogens}

\author{
Muhammad Faraz Khan 1,2,3, Huaqiao Tang ${ }^{2}$, James T. Lyles², Rozenn Pineau ${ }^{2}$, \\ Zia-ur-Rahman Mashwani ${ }^{1}$ and Cassandra L. Quave ${ }^{2,4,5 *}$
}

${ }^{1}$ Department of Botany, Pir Mehr Ali Shah Arid Agriculture University, Rawalpindi, Pakistan, ${ }^{2}$ Center for the Study of Human Health, Emory University College of Arts and Sciences, Atlanta, GA, United States, ${ }^{3}$ Department of Botany, Faculty of Basic and Applied Sciences, University of the Poonch, Rawalakot, Pakistan, ${ }^{4}$ Department of Dermatology, Emory University School of Medicine, Atlanta, GA, United States, ${ }^{5}$ Antibiotic Resistance Center, Emory University, Atlanta, GA, United States

Local people in the Sudhnoti district of Pakistan share a rich practice of traditional medicine for the treatment of a variety of ailments. We selected nine plants from the Sudhnoti ethnopharmacological tradition used for the treatment of infectious and inflammatory disease. Our aim was to evaluate the in vitro anti-infective potential of extracts from these species against multidrug-resistant (MDR) ESKAPE (Enterococcus faecium, Staphylococcus aureus, Klebsiella pneumoniae, Acinetobacter baumanii, Pseudomonas aeruginosa, and Enterobacter species) pathogens. Plant specimens were collected in the Sudhnoti district of Pakistan and vouchers deposited in Pakistan and the USA. Dried bulk specimens were ground into a fine powder and extracted by aqueous decoction and maceration in ethanol. Extracts were assessed for growth inhibitory activity against ESKAPE pathogens and biofilm and quorum sensing activity was assessed in Staphylococcus aureus. Cytotoxicity to human cells was assessed via a lactate dehydrogenase assay of treated human keratinocytes (HaCaTs). Four ethanolic extracts (Zanthoxylum armatum, Adiantum capillus-venaris, Artemisia absinthium, and Martynia annua) inhibited the growth of MDR strains of ESKAPE pathogens ( $\mathrm{IC}_{50}: 256$ $\left.\mu \mathrm{g} \mathrm{mL}{ }^{-1}\right)$. All extracts, with the exception of Pyrus pashia and M. annua, exhibited significant quorum quenching in a reporter strain for $S$. aureus agr $I$. The ethanolic extract of $Z$. armatum fruits (Extract 1290) inhibited quorum sensing $\left(I_{50} 32-256 \mu \mathrm{g} \mathrm{mL}^{-1}\right)$ in S. aureus reporter strains for agr I-III. The quorum quenching activity of extract 1290 was validated by detection of $\delta$-toxin in the bacterial supernatant, with concentrations of 64-256 $\mu \mathrm{g} \mathrm{mL}^{-1}$ sufficient to yield a significant drop in $\delta$-toxin production. None of the extracts inhibited $S$. aureus biofilm formation at sub-inhibitory concentrations for growth. All extracts were well tolerated by human keratinocytes $\left(L_{50} \geq 256 \mu \mathrm{g} \mathrm{mL}^{-1}\right)$. Chemical analysis of extract 1290 by liquid chromatography-Fourier transform mass spectrometry (LC-FTMS) revealed the presence of 29 compounds, including eight with putative structural matches. In conclusion, five out of the nine selected anti-infective medicinal 
plants exhibited growth inhibitory activity against at least one MDR ESKAPE pathogen at concentrations not harmful to human keratinocytes. Furthermore, Z. armatum was identified as a source of quorum quenching natural products and further bioassay-guided fractionation of this species is merited.

Keywords: medicinal plants, biofilm, quorum sensing, Zanthoxylum armatum, delta-toxin

\section{INTRODUCTION}

Antimicrobial resistance (AMR) represents one of the most concerning threats to global health, and new anti-infectives are needed to overcome it (Thabit et al., 2015). AMR occurs when microorganisms are able to survive in the presence of drugs that would normally inhibit their growth (Founou et al., 2017). It is estimated that approximately 700,000 people currently die each year from AMR infections, and this number is projected to reach 10 million annually by the year 2050 (O’Neill, 2016). The Infectious Disease Society of America has highlighted a small group of bacteria (Enterococcus faecium, Staphylococcus aureus, Klebsiella pneumoniae, Acinetobacter baumanni, Pseudomonas aeruginosa, and Enterobacter species), hereafter referred to as ESKAPE pathogens (Boucher et al., 2009), which exhibit resistance to many antibiotic drug classes and are a high priority for drug discovery. Reinvigorating the pipeline of anti-infectives in development is more critical today than ever, as increasingly hard-to-treat bacteria continue to emerge (Pewtrusts.org., 2018). Further, novel anti-infectives that act through new mechanisms of action are needed (Schroeder et al., 2017). Plants represent a promising source of natural products in efforts to identify bioactive compounds (Cowan, 1999; Rossiter et al., 2017).

\section{Role of Plant Natural Products in Anti-infective Drug Discovery}

Plants used in traditional medicinal practices against infections have been found to inhibit growth and virulence of various microbes (Ahmad and Beg, 2001; Kumar et al., 2006; Bibi et al., 2011; Cioch et al., 2017). Traditional medicine is one of the most easily available treatment methods in developing countries, with approximately $80 \%$ of the population in some regions using traditional medicine to meet their primary healthcare needs (WHO, 2002; Maroyi, 2013). Plants synthesize a diverse array of chemicals, known as secondary metabolites, as an adaptation for self-defense and communication with other organisms in their ecosystems (Harborne and Baxter, 1995). These secondary metabolites possess many advantages for anti-infective drug development, including being generally bioactive, being druglike and metabolite-like, and harboring potential for synergy with other secondary metabolites as part of a plant's multicomponent defense system (Harvey et al., 2015).

Most studies on the anti-infective activity of plant extracts have focused on their growth inhibitory potential, and without great success; there are no classic (bacteriostatic or bactericidal) antibiotics derived from plant secondary metabolites on the market. Investigation into alternative anti-infective mechanisms of action can open new avenues in drug development to combat antibiotic resistance (Schroeder et al., 2017), and natural products may serve as a critical reservoir of antibiotic adjuvants to overcome resistance mechanisms (Wright, 2017). One target of great interest, for example, is biofilm production. Biofilms are surface-associated microbial communities that can survive high concentrations of treatment by physically occluding drug entry via the biofilm matrix and through reduction in the rate of cellular metabolism ( $\mathrm{Wu}$ et al., 2015). Inhibiting the formation of biofilms could allow biofilm-associated infections to be more effectively resolved with antibiotic treatment. For example, treatment with an ellagic acid glycoside-rich blackberry extract improved the ability of several functionally distinct classes of antibiotics to significantly reduce the number of biofilmassociated $S$. aureus cells on a medical device (Quave et al., 2012).

Another target of increasing interest is bacterial virulence (Otto, 2004, 2014). In S. aureus, for example, virulence is mediated by quorum sensing, a two-component cell signaling system of stimuli and response based on population density. Many components of $S$. aureus quorum sensing controlled virulence factor production pathways are encoded by the accessory gene regulator ( $a g r$ ) gene locus, of which four subtypes exist: agr I-IV. Quorum quenching (QQ) by agr inhibition has been shown to result in an inhibition of $S$. aureus virulence in a number of studies, including those showing inhibition with plant secondary metabolites (Quave et al., 2015; Muhs et al., 2017).

\section{Plants Are Critical to Anti-infective Traditional Medicine Practices in Pakistan}

The majority of people in Pakistan rely on medicinal plants for the treatment of ailments; $12 \%$ of Pakistani flora are used in medicine and more than 300 medicinal plants are traded for this purpose (Shinwari, 2010). Due to its geographic position, ethnopharmacological practices in Pakistan stem from Ayurvedic, Islamic and local traditional medicine (Shaikh and Hatcher, 2005). Traditional Unani medicine is also popular among a large segment of the country (Qureshi et al., 2009). The northern part of Pakistan, including the State of Jammu and Kashmir, is rich with medicinal plants, providing the main supply of raw herbal products to herbal manufacturers (davakhanas) and the international market (Shinwari, 2010). Nine medicinal plant species were selected for this study based on observations of traditional use for the treatment of infectious and inflammatory diseases during fieldwork (Fluck and Jaspersen Schib, 1941) and literature searches on their reported traditional uses and known activities. We selected species with no prior or limited antibacterial analysis (e.g., only examined for growth inhibition via agar well or disc diffusion methods). All selected species 
are present in abundant populations in the collection region and none are listed as threatened or endangered. The aims of our study were to evaluate the impact of extracts from the following medicinal plants on (1) the growth of ESKAPE pathogens; (2) the biofilm and quorum sensing capacity of S. aureus; (3) mammalian cytotoxicity in human keratinocytes; and to (4) chemically characterize the most bioactive extract(s). We focused our biofilm and quorum quenching assays on $S$. aureus as a proof of concept to demonstrate other potential pathways through which anti-infective plant extracts may act; we did not have the appropriate biofilm deficient mutant control strains or reporter model systems for the other ESKAPE pathogens available to test in this study. We have summarized the ethnopharmacological basis for the selection of each species below:

- Adiantum capillus-veneris L., Pteridaceae, is a fern commonly found in moist temperate regions of the Himalayas. It is commonly used as an aqueous infusion to treat urinary tract infections (UTIs). It is also used as an astringent, demulcent, antitussive and diuretic (Ishaq et al., 2014).

- Artemisia absinthium L., Asteraceae, is used topically as a paste of aerial plant parts for pruritus and inflammatory and infectious skin disorders (Khan and Khatoon, 2008). A number of Artemisia species have traditional uses, and several have been utilized for the development of drugs against malaria and typhoid (Hayat et al., 2009).

- Berberis lycium Royle, Berberidaceae, is a prickly shrub traditionally used to treat diarrhea, cholera and piles (Malik et al., 2017). Other indications include jaundice, diabetes, eye infections, fractured bones, internal wounds and diarrhea (Ali et al., 2015). Bark infusions are traditionally used for oral infections, toothaches and earaches (Abbasi et al., 2010).

- Gentiana olivieri Griseb., Gentianaceae is an herb found abundantly in the alpine and sub-alpine areas of the Himalayas. Its traditional medical use is as a root decoction for the treatment of urinary rentention (Ali and Qaiser, 2009; Bano et al., 2014).

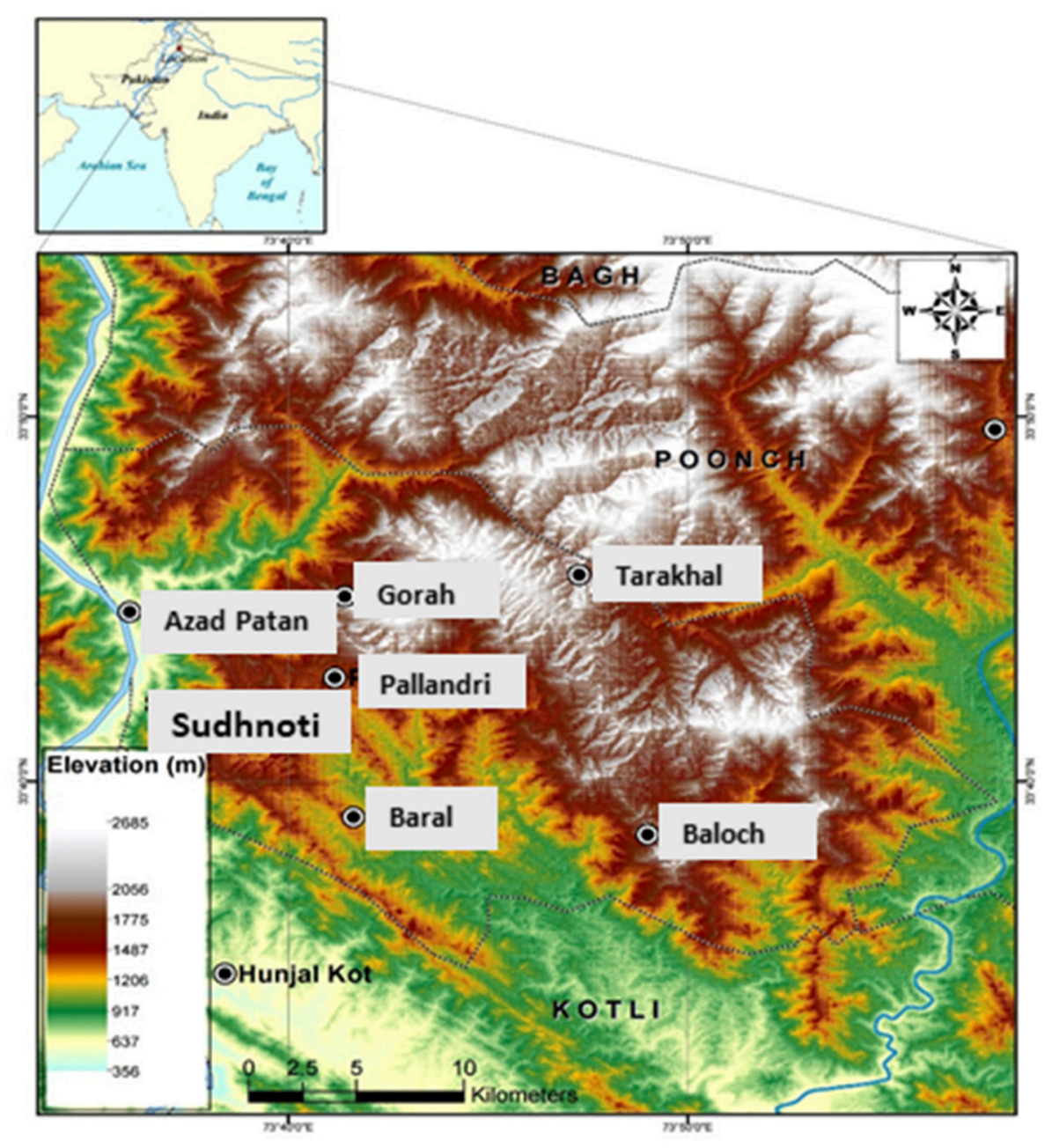

FIGURE 1 | Map of the study region: Sudhnoti district in Northern Pakistan. 
TABLE 1 | Plant species tested with a description of parts used, extraction solvent, and percent yield obtained for each extract.

\begin{tabular}{|c|c|c|c|c|c|c|c|}
\hline Family & Species & Voucher ID & $\begin{array}{c}\text { GEO accession } \\
\text { number* }\end{array}$ & Part used & $\begin{array}{l}\text { Extract } \\
\text { ID }\end{array}$ & $\begin{array}{l}\text { Extract } \\
\text { solvent }\end{array}$ & $\begin{array}{l}\text { Percent } \\
\text { yield (\%) }\end{array}$ \\
\hline Apocynaceae & Nerium oleander L. & FK-102 & 22,199 & Leaves & $\begin{array}{l}1292 \\
1298\end{array}$ & $\begin{array}{l}\mathrm{EtOH} \\
\mathrm{dH}_{2} \mathrm{O}\end{array}$ & $\begin{array}{l}14.72 \\
15.81\end{array}$ \\
\hline Asteraceae & Artemisia absinthium L. & FK-106 & 22,195 & Aerial parts & $\begin{array}{l}1308 \\
1311\end{array}$ & $\begin{array}{l}\mathrm{EtOH} \\
\mathrm{dH}_{2} \mathrm{O}\end{array}$ & $\begin{array}{l}17.68 \\
11.89\end{array}$ \\
\hline Berberidaceae & Berberis lycium Royle & FK-105 & 22,196 & Root & $\begin{array}{l}1289 \\
1295\end{array}$ & $\begin{array}{l}\mathrm{EtOH} \\
\mathrm{dH}_{2} \mathrm{O}\end{array}$ & $\begin{array}{c}13.94 \\
7.5\end{array}$ \\
\hline \multirow[t]{2}{*}{ Gentianaceae } & Gentiana olivieri Griseb. & FK-104 & 22,197 & Aerial parts & $\begin{array}{l}1293 \\
1299\end{array}$ & $\begin{array}{l}\mathrm{EtOH} \\
\mathrm{dH}_{2} \mathrm{O}\end{array}$ & $\begin{array}{l}9.68 \\
6.54\end{array}$ \\
\hline & Swertia chirata Buch.-Ham. ex C.B. Clarke & FK-103 & 22,198 & Whole plant & $\begin{array}{l}1291 \\
1297\end{array}$ & $\begin{array}{l}\mathrm{EtOH} \\
\mathrm{dH}_{2} \mathrm{O}\end{array}$ & $\begin{array}{c}6.67 \\
20.25\end{array}$ \\
\hline Martyniaceae & Martynia annua L. & FK-735 & - & Fruit & $\begin{array}{l}1310 \\
1312\end{array}$ & $\begin{array}{l}\mathrm{EtOH} \\
\mathrm{dH}_{2} \mathrm{O}\end{array}$ & $\begin{array}{l}7.92 \\
2.41\end{array}$ \\
\hline Pteridaceae & Adiantum capillus-veneris L. & FK-108 & 22,194 & Whole plant & 1294 & $\mathrm{EtOH}$ & 3.19 \\
\hline Rosaceae & Pyrus pashia Buch.-Ham. ex D. Don & FK-101 & 22,200 & Fruit & $\begin{array}{l}1309 \\
1322\end{array}$ & $\begin{array}{r}\mathrm{dH}_{2} \mathrm{O} \\
\mathrm{EtOH}\end{array}$ & $\begin{array}{c}18.44 \\
2.38\end{array}$ \\
\hline Rutaceae & Zanthoxylum armatum DC. & FK-73 & 22,201 & Fruit & $\begin{array}{l}1290 \\
1296\end{array}$ & $\begin{array}{l}\mathrm{EtOH} \\
\mathrm{dH}_{2} \mathrm{O}\end{array}$ & $\begin{array}{l}7.50 \\
7.27\end{array}$ \\
\hline
\end{tabular}

*GEO: Emory University Herbarium.

- Martynia annua L., Martyniaceae, is an herbaceous, erect, glandular herb commonly known as "bichoo." It grows in locations with ample organic matter, i.e., landfills. Leaf paste is traditionally topically applied to infected wounds and skin conditions. Leaf juice is used for wound healing and in gargles for sore throat (Santram and Singhai, 2011; Dhingra et al., 2013).

- Nerium oleander L., Apocynaceae, is commonly known as "kneer." It is used for the treatment of oral and topical infections (Hussain and Gorsi, 2004). Young branches are used as chewing sticks to treat oral infections by indigenous communities in Himalayan valleys.

- Pyrus pashia Buch.-Ham. ex D.Don, Rosaceae, is a woody plant in the rose family with edible fruit. It is locally used as a laxative and to treat gastrointestinal, cardiovascular and respiratory ailments (Abbasi et al., 2013; Janbaz et al., 2015).

- Swertia chirata Buch.-Ham. ex C.B. Clarke, Gentianaceae, is widely used as a whole plant infusion by local people for the treatment of hepatitis, inflammation and digestive diseases. Other indications include chronic fever, malaria, skin disease and bronchial infections (Kumar and Van Staden, 2016).

- Zanthoxylum armatum DC., Rutaceae, locally known as "timber" has been used by local people as a chewing stick to treat dental infections and oral sores. The fruits and bark of the plant are also reportedly used to treat cancer and digestive ailments such as cholera and dysentery (Ahmad et al., 2014; Alam and us Saqib, 2017).

\section{MATERIALS AND METHODS}

\section{Plant Collection and Identification}

Plant material was collected from the Sudhnoti district in Northern Pakistan (Figure 1) during an ethnobotanical survey conducted from Fall 2015 to Spring 2017. Nine medicinal species were selected for collection based on their potential against infectious diseases as determined by traditional use and depth of available research reported in the literature. Plant collections were made on private land with permission of local owners and community representatives following the World Health Organization Guidelines on good agricultural and collection practices for medicinal plants (WHO, 2003). Bulk plant material was separated into parts, which were then clipped into small pieces and dried in the shade. Voucher specimens of each species were prepared for identification and deposited in herbaria in Pakistan and the USA (PMAS-UAAR and GEO).

Identification of plant specimens was carried out with the assistance of Dr. Rehmatullah Qureshi (PMAS-UAAR, Pakistan) and Dr. Tharangamala Samarakoon (GEO: Emory University Herbarium, USA). Dry plant material was imported to the USA under an import permit issued by the United States Department of Agriculture (Permit Number: PCIP-17-00110). Plant material was stored at $-80^{\circ} \mathrm{C}$ upon arrival. Voucher specimens (listed in Table 1) deposited at GEO were digitized for open access viewing on a web-based platform (SERNEC, 2017) ${ }^{1}$. The Plant List was consulted for family assignment and confirmation of latest botanical names (TPL, 2017), and the Angiosperm Phylogeny Group IV was used for family assignments (APG, 2016).

\section{Preparation of Extracts}

Following shipment and storage at $-80^{\circ} \mathrm{C}$, plant materials were dried at $35^{\circ} \mathrm{C}$ in a dehumidifying drier for 3 days and ground into fine powder ( $2 \mathrm{~mm}$ mesh size) with a Thomas Scientific Wiley Mill (Swedesboro, NJ). Retention vouchers of chopped and ground material were prepared for future reference. For

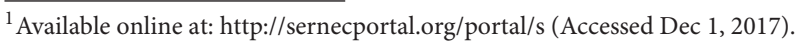


the preparation of organic crude extracts, plant powder was macerated for $72 \mathrm{~h}$ in $1 \mathrm{~L}$ flasks at a 1:10 ratio (w/v) in 95\% ethanol with daily agitation. Macerates were filtered, the marc collected, and residual plant material subjected to a repeat extraction in $95 \%$ ethanol. Solvent was removed by rotary evaporation at $\leq 40^{\circ} \mathrm{C}$. Extracts were redissolved in deionized water $\left(\mathrm{dH}_{2} \mathrm{O}\right)$, shell frozen in a dry ice-acetone bath, and then lyophilized overnight on a Labconco FreeZone 2.5 Lyophilizer (Kansas City, MO). Dry extracts were stored in scintillation vials at $-20^{\circ} \mathrm{C}$.
Aqueous extracts were prepared by boiling 30-40 g of plant material $(1: 10$ ratio $\mathrm{w} / \mathrm{v})$ for $20 \mathrm{~min}$ in $\mathrm{dH}_{2} \mathrm{O}$ on a hot plate, followed by centrifugation and vacuum filtration. Aqueous extracts were then evaporated on a rotary evaporator and subsequently lyophilized as described above. Organic and aqueous crude extracts of all the plant samples were dissolved in DMSO or $\mathrm{dH}_{2} \mathrm{O}$, respectively, to a stock concentration of $10 \mathrm{mg} \mathrm{mL} \mathrm{m}^{-1}$ prior to testing in biological assays.

TABLE 2 | ESKAPE pathogens tested and their corresponding antibiotic resistance profiles as reported by the source provider (BEI Resources or CDC AR Bank) or as determined by antibiotic disc diffusion test (for AMC, IPM, PIP, RA, SXT, and TET) following CLSI breakpoints.

\begin{tabular}{|c|c|c|c|c|}
\hline Species & Strain ID & Alternate ID & Antibiotic resistance profile* & Other characteristics \\
\hline \multirow[t]{2}{*}{ Acinetobacter baumannii } & CDC-33 & AR-BANK \#0033 & $\begin{array}{l}\text { CAZ, CIP, CRO, CTX, DOR, FEP, GEN, } \\
\text { IPM, LVX, MEM, SAM, SXT, TOB, TZP }\end{array}$ & $\begin{array}{l}\text { reduced susceptibility, elevated } \\
\text { carbapenem MICs }\end{array}$ \\
\hline & EU-24 & Naval-81; NR-17786 & PIP, SXT, TET, TZP, & \\
\hline Enterobacter aerogenes & CDC-7 & AR-BANK \#0007 & $\begin{array}{c}\text { AMC, AMP, ATM, CAZ, CFZ, CIP, CRO, } \\
\text { CTX, ETP, FEP, FOX, LVX, SAM, TET }\end{array}$ & $\begin{array}{l}\text { reduced susceptibility, elevated } \\
\text { carbapenem MICs }\end{array}$ \\
\hline Enterobacter cloacae & CDC-32 & AR-BANK \#0032 & $\begin{array}{l}\text { AMC, AMP, ATM, CAZ, CFZ, CRO, CTX, } \\
\text { ETP, FEP, FOX, IPM, MEM, SAM, SXT, TZP }\end{array}$ & $\begin{array}{l}\text { reduced susceptibility, elevated } \\
\text { carbapenem MICs }\end{array}$ \\
\hline \multirow[t]{2}{*}{ Enterococcus faecium } & EU-44 & HM-959; Strain 513 & AMC, RA, SXT, TET, TZP & \\
\hline & EU-49 & NR-31915; Strain E0164 & AMC, GEN, TET, SXT, TZP, VAN & \\
\hline \multirow[t]{2}{*}{ Klebsiella pneumoniae } & EU-32 & NR-15410 & AMC, PIP, SXT, TZP & $\begin{array}{l}\text { Contains } \beta \text {-lactamase } K \text {. pneumoniae } \\
\text { carbapenemase (blaKPC) gene }\end{array}$ \\
\hline & CDC-76 & AR-BANK \#0076 & $\begin{array}{c}\text { AMC, AMP, CAZ, CFZ, CTX, DOR, FEP, } \\
\text { FOX, GEN, IPM, MEM, SAM, SXT, TOB, } \\
\text { TZP }\end{array}$ & $\begin{array}{l}\text { reduced susceptibility, elevated } \\
\text { carbapenem MICs }\end{array}$ \\
\hline \multirow[t]{2}{*}{ Pseudomonas aeruginosa } & CDC-54 & AR-BANK \#0054 & $\begin{array}{c}\text { CAZ, FEP, GEN, IPM, LVX, MEM, TOB, } \\
\text { TZP }\end{array}$ & \\
\hline & $\mathrm{PAO} 1$ & $\mathrm{AH}-0071$ & & \\
\hline \multirow[t]{12}{*}{ Staphylococcus aureus } & LAC & $\mathrm{AH} 0845$ & OXA, PIP & PFGE: USA300; CA-MRSA \\
\hline & UAMS-1 & & & $\begin{array}{l}\text { Osteomyelitis clinical isolate; prototype } \\
\text { biofilm isolate }\end{array}$ \\
\hline & UAMS-929 & & & $\begin{array}{l}\text { Isogenic } \Delta \text { sarA mutant of UAMS-1, biofilm } \\
\text { deficient control strain }\end{array}$ \\
\hline & $\mathrm{AH} 1677$ & & & $\begin{array}{l}\text { agr I yfp reporter strain (chloramphenicol } \\
\text { resistant) }\end{array}$ \\
\hline & $\mathrm{AH} 430$ & & & agr II yfp reporter strain \\
\hline & $\mathrm{AH} 1747$ & & & agr III yfp reporter strain \\
\hline & AH1872 & & & agr IV yfp reporter strain \\
\hline & NRS232 & НТ20020065 & ERY', GEN, PEN & $\begin{array}{l}\text { agr l, egc+, (lukS-lukF PVL)+, hlg+; } \\
\text { associated with necrotising pneumonia }\end{array}$ \\
\hline & NRS242 & НТ20020238 & ERY', PEN & $\begin{array}{l}\text { agr IV, egc+, (lukS-lukF PVL)+, } \\
\text { (lukE-lukD)+, hlgv+; associated with } \\
\text { impetigo }\end{array}$ \\
\hline & NRS245 & HT20020320; NR-46038 & CIP, OXA, PEN & $\begin{array}{l}\text { agr I, sea+, sed+, (lukE-lukD)+, hlgv+; } \\
\text { associated with impetigo; SCCmec type IV }\end{array}$ \\
\hline & NRS249 & HT20020341; NR-46042 & CIP, CLI, ERY, GEN, OXA, PEN & $\begin{array}{l}\text { agr I, sea+, (lukE-lukD)+, hlgv+ } \\
\text { associated with native valve endocarditis; } \\
\text { sCCmec type IV }\end{array}$ \\
\hline & NRS385 & 95938; NR-46071 & CIP, CLI, ERY, GEN, LVX, SXT, TET & $\begin{array}{l}\text { agr I; PFT is USA500, MLST is ST8, spa } \\
\text { type is YHGCMBQBLO, SCCmec IV; } \\
\text { sea+, seb+; HA-MRSA }\end{array}$ \\
\hline
\end{tabular}

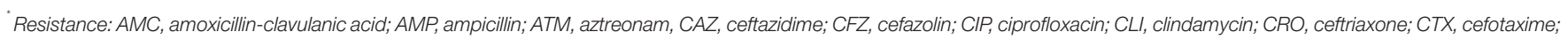

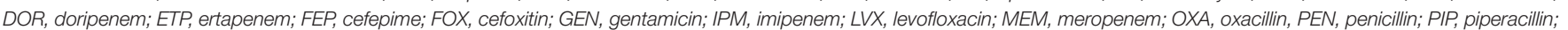

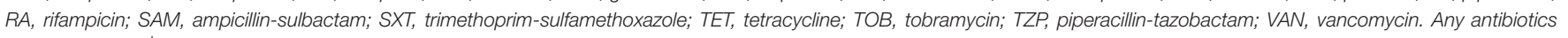
denoted with an' indicates intermediate resistance. 


\section{Antibacterial Testing \\ Bacterial Strains and Cultures}

Twenty-two strains from seven bacterial species were used in this study (Table 2). These strains comprise drug resistant bacteria recognized by the American Society of Microbiology as ESKAPE pathogens: Enterococcus faecium (EU-49, EU44), Staphylococcus aureus (UAMS-1, UAMS-929, LAC, AH1677, AH430, AH1747, AH1872, NRS225, NRS232, NRS242, NRS249, NRS385), Klebsiella pneumoniae (EU-32, CDC-76), Acinetobacter baumannii (CDC-33, EU-24), Pseudomonas aeruginosa (CDC-54, PAO1), Enterobacter cloacae (CDC-32), and Enterobacter aerogenes (CDC-7). Antibiotic resistance profiles and other strain characteristics are reported in Table 2. All strains were streaked from freezer stock onto tryptic soy agar (TSA) plates and incubated at $37{ }^{\circ} \mathrm{C}$ overnight before making overnight liquid cultures in cation-adjusted Mueller-Hinton broth (CAMHB) or tryptic soy broth (TSB). All antibacterial tests were conducted in triplicate and repeated at least once on a separate day, and included appropriate positive (antibiotics, biofilm inhibitors, or virulence inhibitors) and negative controls, including vehicle and media controls.

\section{Growth Inhibition Assay}

Extracts were examined for growth inhibitory activity following the guidelines of the Clinical and Laboratory Standards Institute for broth microdilution testing (CLSI, 2013). Overnight cultures were diluted in Cation-adjusted Muller Hinton broth (CAMHB) based on their optical density $\left(\mathrm{OD}_{600 \mathrm{~nm}}\right)$ to a confluence of $5 \times 10^{5} \mathrm{CFU} \mathrm{mL} \mathrm{m}^{-1}$, confirmed by plate counts. Assays were performed in 96-well plates (Greiner Bio-One International,
CELLSTAR 655-185). Plates were incubated for $18-24 \mathrm{~h}$, depending upon the test recommendations for the species (CLSI, 2013), at which point they were read at an $O_{600 \mathrm{~nm}}$ in a Cytation-3 multimode plate reader (Biotek). The percent of growth inhibition was calculated using a previously described formula that takes into account extract color (Quave et al., 2008). The $\mathrm{IC}_{50}$ was defined as the concentration required to achieve $\geq 50 \%$ inhibition of growth, as determined by OD. The MIC was defined as the concentration required to achieve an optically clear well (equivalent to the $\mathrm{IC}_{90}$, or concentration required to achieve $\geq 90 \%$ inhibition of growth as determined by $\mathrm{OD}_{600 \mathrm{~nm}}$ ).

\section{Biofilm Inhibition Assay}

The biofilm inhibiting activity of extracts was assessed using biofilm media with human plasma in a static microtiter plate crystal violet assay as previously described (Quave et al., 2012) against $S$. aureus UAMS-1 with its isogenic biofilm deficient mutant UAMS-929 as a positive control (Beenken et al., 2003). A previously reported biofilm inhibiting extract, 220D-F2 from Rubus ulmifolius (Quave et al., 2012), was used as a positive chemical control.

\section{Agr Reporter Assay for Quorum Sensing Inhibition}

Quorum sensing inhibition activity also known as quorum quenching of the plant extracts was assessed against all four accessory gene regulator (agr) subtypes of $S$. aureus. Fluorescent reporter strains (AH1672, AH430, AH1747, and AH1872, Table 2) were used as previously described (Quave and Horswill, 2014; Muhs et al., 2017). Controls included vehicles (DMSO and $\mathrm{dH}_{2} \mathrm{O}$ ) and $224 \mathrm{C}-\mathrm{F} 2$, a previously reported quorum sensing

TABLE 3 | Summary of organic $(\mathrm{EtOH})$ and aqueous extracts exhibiting growth inhibition $\geq 50 \%\left(\mathrm{IC}_{50}\right)$ against ESKAPE pathogens when screened at $256 \mu \mathrm{g} \mathrm{mL}^{-1}$.

\begin{tabular}{|c|c|c|c|c|c|c|c|c|c|c|c|c|c|}
\hline \multirow[t]{2}{*}{ Plant Species } & \multirow[t]{2}{*}{ Extract ID } & \multicolumn{2}{|c|}{ A. baumannii } & \multirow{2}{*}{$\begin{array}{l}\text { E. aerogenes } \\
\text { CDC-7 }\end{array}$} & \multirow{2}{*}{$\begin{array}{l}\text { E. cloacae } \\
\text { CDC-32 }\end{array}$} & \multicolumn{2}{|c|}{ E. faecium } & \multicolumn{2}{|c|}{ K. pneumoniae } & \multicolumn{2}{|c|}{ P. aeruginosa } & \multicolumn{2}{|c|}{ S. aureus } \\
\hline & & CDC-33 & EU-24 & & & EU-44 & EU-49 & EU-32 & CDC-76 & CDC-54 & PA01 & LAC & UAMS-1 \\
\hline \multirow[t]{2}{*}{ Nerium oleander } & 1292 & - & - & - & - & - & - & - & - & - & - & - & - \\
\hline & 1298 & - & - & - & - & - & - & - & - & - & - & - & - \\
\hline \multirow[t]{2}{*}{ Artemisia absinthium } & 1308 & - & - & - & - & + & + & - & - & - & - & - & + \\
\hline & 1311 & - & - & - & - & - & - & - & - & - & - & - & - \\
\hline \multirow[t]{2}{*}{ Berberis lycium } & 1289 & - & - & - & - & - & - & - & - & - & - & - & - \\
\hline & 1295 & - & - & - & - & - & - & - & - & - & - & - & - \\
\hline \multirow[t]{2}{*}{ Gentiana olivieri } & 1293 & - & - & - & - & - & - & - & - & - & - & - & - \\
\hline & 1299 & - & - & - & - & - & - & - & - & - & - & - & - \\
\hline \multirow[t]{2}{*}{ Swertia chirata } & 1291 & - & - & - & - & - & - & - & - & - & - & + & - \\
\hline & 1297 & - & - & - & - & - & - & - & - & - & - & - & - \\
\hline \multirow[t]{2}{*}{ Martynia annua } & 1310 & + & - & - & - & + & - & + & - & - & - & + & + \\
\hline & 1312 & - & - & - & - & - & - & - & - & - & - & - & - \\
\hline Adiantum capillus-veneris & 1294 & - & - & - & - & + & + & - & - & - & - & + & + \\
\hline \multirow[t]{2}{*}{ Pyrus pashia } & 1309 & - & - & - & - & - & - & - & - & - & - & - & - \\
\hline & 1322 & - & - & - & - & - & - & - & - & - & - & - & - \\
\hline \multirow[t]{2}{*}{ Zanthoxylum armatum } & 1290 & - & - & - & - & + & + & - & - & - & - & + & + \\
\hline & 1296 & - & - & - & - & - & - & - & - & - & - & - & - \\
\hline
\end{tabular}

"+": growth inhibition $\geq 50 \%$ in comparison to vehicle control; "- ": < 50\% growth inhibition in comparison to vehicle control.

Dose-response curves for active extracts are reported in Figure 2. 
inhibitor extract (Quave et al., 2015). Quorum quenching activity was expressed as a percent vehicle value of the reporter strains' yellow fluorescent protein (YFP) signal. The $\mathrm{IC}_{50}$ and $\mathrm{IC}_{90}$ represent the concentration necessary to inhibit $\geq 50$ or $\geq 90 \%$ of signaling, respectively, in comparison to the vehicle control. All extracts were initially screened against an $a g r$ I reporter strain at $256 \mu \mathrm{g} \mathrm{mL}^{-1}$. Dose response curves were obtained by 2 -fold serial dilutions of treatments at a concentration range of 8-256 $\mu \mathrm{g} \mathrm{mL} L^{-1}$.

\section{$\delta$-Toxin Inhibition}

Levels of $\delta$-toxin (also known as $\delta$-hemolysin) production in extract-treated culture supernatant were quantified by HPLC using a previously described protocol (Quave and Horswill, 2018) in order to determine if the agr inhibitory activity of extract 1290 (EtOH extract of Z. armatum) observed in the reporter assay corresponded with a decline in exotoxin production. The amount of $\delta$-toxin present in the supernatant of treated and untreated culture samples was quantified using high toxin producing strains of S. aureus: NRS 225, NRS 232, NRS 242, NRS 249, NRS385 and LAC (Table 2). Extract 224C-F2 was used as a positive control (Quave et al., 2015).

\section{Mammalian Cytotoxicity Assay}

Human skin keratinocytes (HaCaTs) and a lactate dehydrogenase $(\mathrm{LDH})$ test kit (G-Biosciences, St. Louis, MO) were used to assess the potential cytotoxicity of extracts as previously described (Quave et al., 2015). All extracts were tested at a concentration of $100 \mu \mathrm{g} \mathrm{mL}{ }^{-1}$. Extract 1290 was further evaluated at a concentration range of $8-1,024 \mu \mathrm{g} \mathrm{mL}^{-1}$. Percent DMSO v/v for all tests was $<2 \%$.
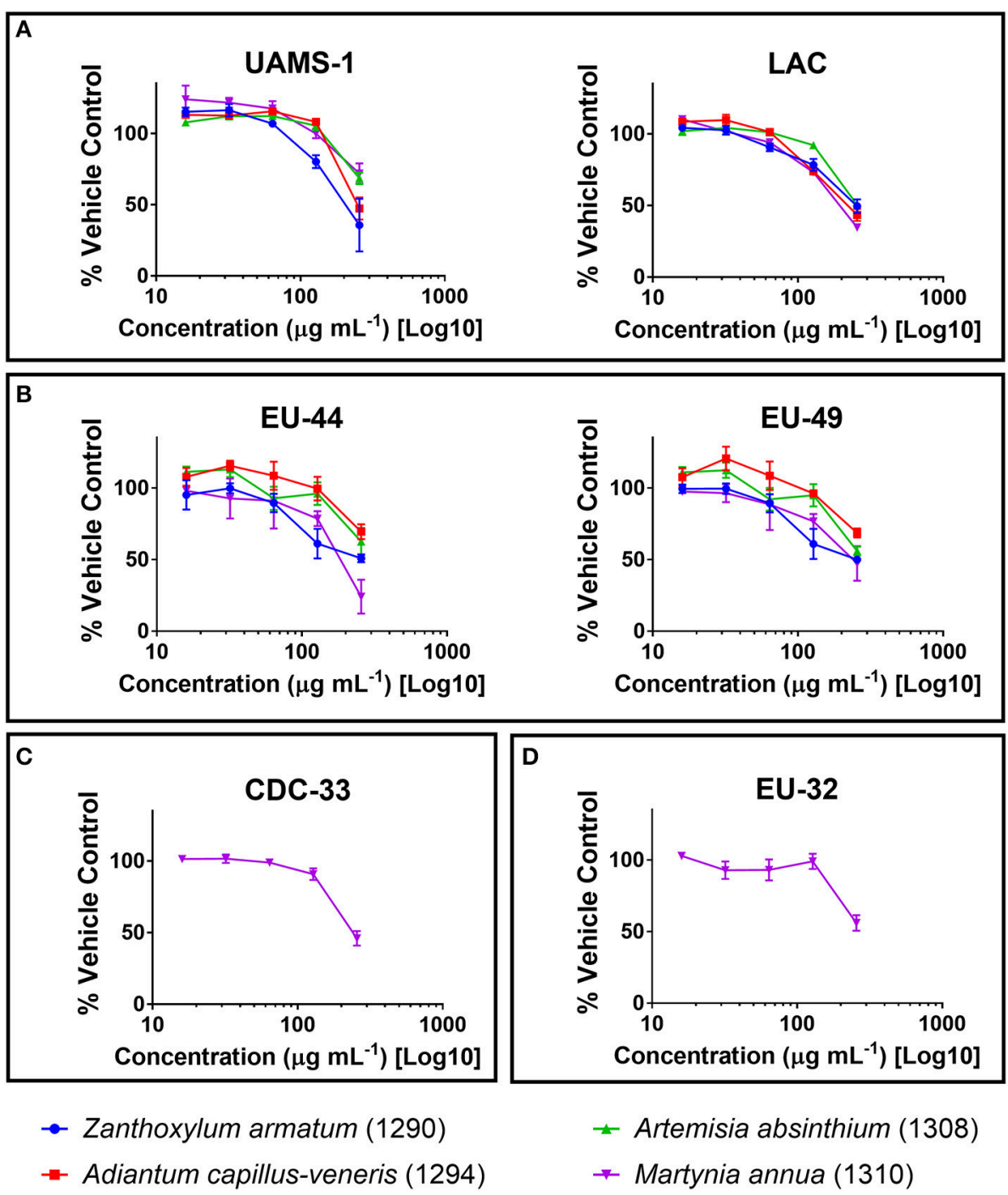

FIGURE 2 | Growth inhibitory activity of ethanolic extracts that reached an $\mathrm{IC}_{50}$ against (A) Staphylococcus aureus; (B) Enterococcus faecium; (C) Acinetobacter baumannii; and (D) Klebsiella pneumoniae, reported as percent of the vehicle-treated control (DMSO). 

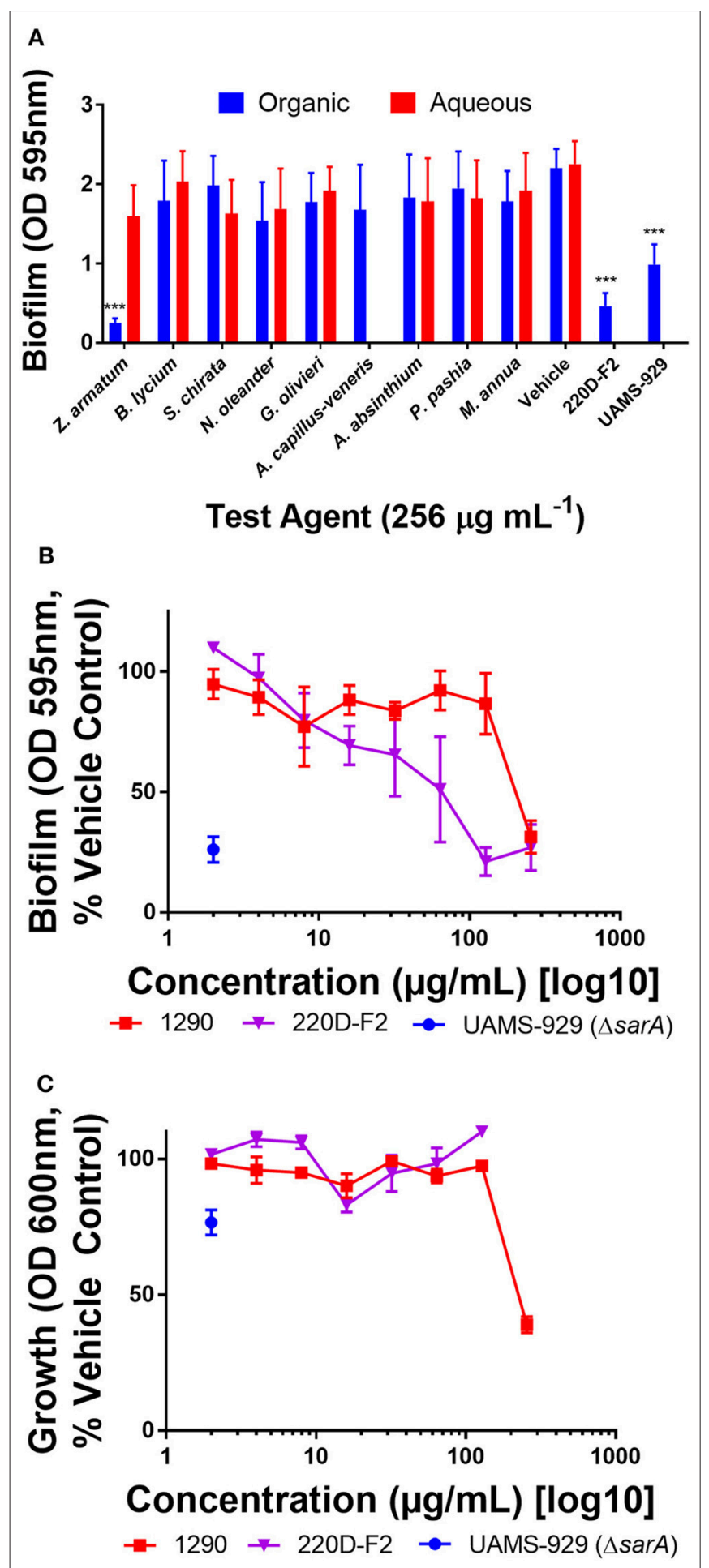

FIGURE 3 | Impact of extracts on biofilm formation in S. aureus (UAMS-1). (A) Biofilm inhibition of extracts at $256 \mu \mathrm{g} \mathrm{mL}^{-1}$. (B) Biofilm dose-response study with extract 1290, Z. armatum fruit ethanolic extract. (C) Growth dose response study with extract $1290, Z$. armatum fruit ethanolic extract. Positive controls included the biofilm deficient isogenic sarA mutant of UAMS-1 (UAMS-929) and a previously documented biofilm inhibiting extract, 220D-F2 (Quave et al., 2012). Significance was determined in comparison to the vehicle control, with ${ }^{*} p<0.05,{ }^{* *} p<0.01$, and ${ }^{* * *} p<0.001$.

\section{Chemical Characterization}

High Performance Liquid Chromatography (HPLC)

$\mathrm{EtOH}$ extracts of $Z$. armatum, $A$. capillus-veneris and $A$. absinthium were characterized by HPLC. The HPLC method was adapted from a previously published method (Bhatt et al., 2017). An Agilent Eclipse XDB-C18 $4.6 \times 250 \mathrm{~mm}, 5 \mu \mathrm{m}$ analytical column with compatible guard column at $25^{\circ} \mathrm{C}$ was used for analysis. Extracts were prepared at $10 \mathrm{mg} \mathrm{mL}^{-1}$ in $70: 20: 10$ ACN:MeOH: $\mathrm{dH}_{2} \mathrm{O}$. A $20 \mu \mathrm{L}$ sample injection was eluted at a flow rate of $1 \mathrm{~mL} \mathrm{~min}-1$ using a mobile phase consisting of (A) $0.1 \%$ formic acid in $\mathrm{dH}_{2} \mathrm{O}$, (B) $0.1 \%$ formic acid in ACN. The linear gradient had initial conditions of $98: 2 \mathrm{~A}: \mathrm{B}$ at $0 \mathrm{~min}$, changing to 90:10 A:B at $19 \mathrm{~min}$, then to $85: 15 \mathrm{~A}: \mathrm{B}$ at $59 \mathrm{~min}$, and reaching $0: 100 \mathrm{~A}: \mathrm{B}$ at $100 \mathrm{~min}$; this was maintained until $125 \mathrm{~min}$, then the column was returned to initial conditions 98:2 A:B and held for $9 \mathrm{~min}$. Data were collected with a diode array detector from 190 to $600 \mathrm{~nm}$ for all samples.

\section{Mass Spectrometry}

LC-FTMS was performed on the bioactive ethanol extract of $Z$. armatum (1290) using a Thermo Scientific LTQ-FT Ultra MS equipped with a Shimadzu SIL-ACHT and Dionex 3600SD HPLC pump. For chromatography, the same sample preparations, HPLC column, and mobile phases were used as in the previously described HPLC method. Data were acquired in $\mathrm{MS}^{1}$ mode scanning from an $\mathrm{m} / \mathrm{z}$ of $150-1,500$ in negative and positive ESI (electrospray ionization) mode and processed with Thermo Scientific Xcalibur 2.2 SP1.48 (San Jose, CA). The capillary temperature was $275.0^{\circ} \mathrm{C}$, sheath gas of 60 , source voltage 5.00 $\mathrm{kV}$, source current $100.0 \mu \mathrm{A}$, and the capillary voltage -19.0 or $+32.0 \mathrm{~V}$ for negative and positive modes, respectively. Putative formulas were determined by performing isotope abundance analysis on the high-resolution mass spectral data with X-caliber software and reporting the most closely matching empirical formula. Database searches were performed using Scifinder (American Chemical Society) and the Dictionary of Natural Products (Taylor \& Francis Group). The databases were reviewed for compounds identified from the genus Zanthoxylum with molecular masses corresponding to the LC-FTMS data.

\section{Statistical Analyses}

All data were analyzed using a two-tailed Student's $t$-test as calculated by GraphPad Prism 7 software (GraphPad Software, La Jolla, CA). DMSO or $\mathrm{dH}_{2} \mathrm{O}$ treated (vehicle control) cultures were used as a vehicle control and were compared to those treated with extract for all statistical analyses. $P<0.05$ were considered statistically significant. All assays and other experiments were performed in triplicate or quadruplicate, and repeated on two separate days.

\section{RESULTS}

\section{Antibacterial Activity Extracts Exhibit Limited Growth Inhibitory Activity in ESKAPE Pathogens}

Crude extracts of the selected plant species (Table 1) were screened against ESKAPE pathogens at a concentration of 256 
$\mu \mathrm{g} \mathrm{mL} \mathrm{m}^{-1}$ in broth microdilution assays. None of the organic extracts exhibited an $\mathrm{IC}_{50}$ against Enterobacter aerogenes (CDC7), E. cloacae (CDC-32), or Pseudomonas aeruginosa (CDC54 or PAO1) (Table 3), and the aqueous extracts did not exhibit an $\mathrm{IC}_{50}$ against any strain. The ethanolic extract of $M$. annua was the only extract to exhibit an $\mathrm{IC}_{50}$ against an Acinetobacter baumannii strain (CDC-33). This $M$. annua extract also exhibited an $\mathrm{IC}_{50}$ for one strain of E. faecium (EU-44), one strain of Klebsiella pneumoniae (EU-32), and both strains of Staphylococcus aureus (LAC and UAMS-1) tested for growth inhibition. Z. armatum and A. capillus-veneris ethanolic extracts both exhibited an $\mathrm{IC}_{50}$ against both strains of $E$. faecium and $S$. aureus tested. The other plant species tested ( $N$. oleander, $B$. lycium, G. oliverieri and P. pashia) did not meet the threshold of $50 \%$ inhibition of growth at the screening concentration (256 ug $\mathrm{mL}^{-1}$ ). Dose dependent inhibition of $S$. aureus (LAC and UAMS-1) and Enterococcus faecium (EU44 and EU49) growth was demonstrated by the ethanol extracts of $Z$. armatum, A. capillus-venaris, $A$. absinthium, and $M$. annua, with $\mathrm{IC}_{50}$ values of $256 \mu \mathrm{g} \mathrm{mL}^{-1}$ for S. aureus and E. faecium, respectively. The
A

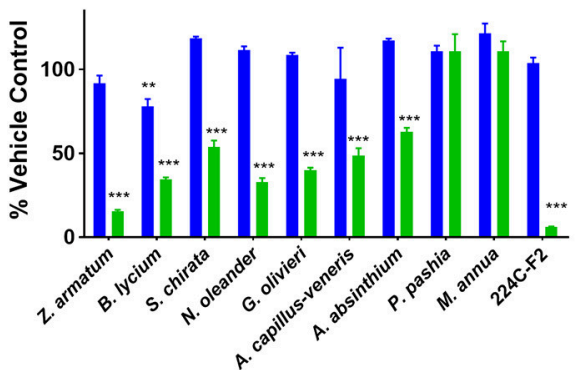

Test Agent $\left(256 \mu \mathrm{g} \mathrm{mL}^{-1}\right)$

- Growth (OD 600nm)

Quorum Sensing (FLD)

c $\operatorname{agrl}(\mathrm{AH} 1677)$

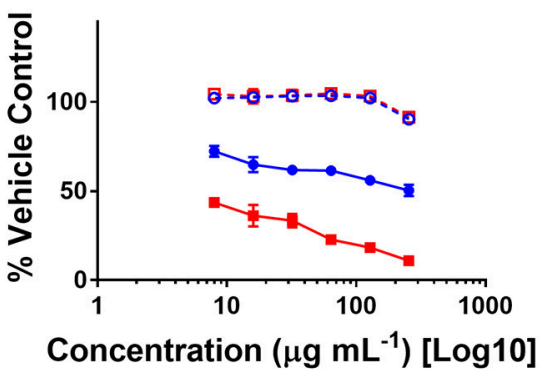

agr III (AH1747)

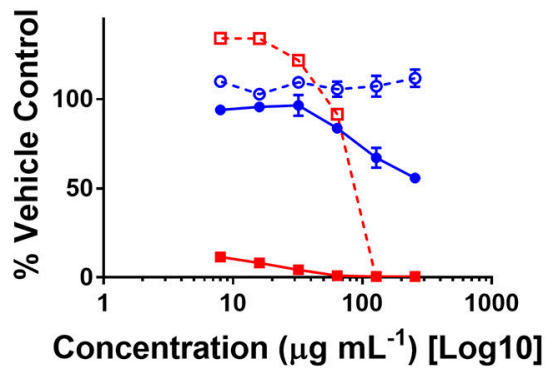

B

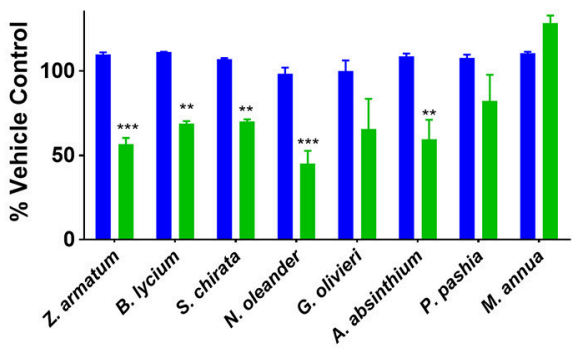

Test Agent $\left(256 \mu \mathrm{g} \mathrm{mL}^{-1}\right)$

- Growth (OD 600nm) Quorum Sensing (FLD)

agr II (AH430)

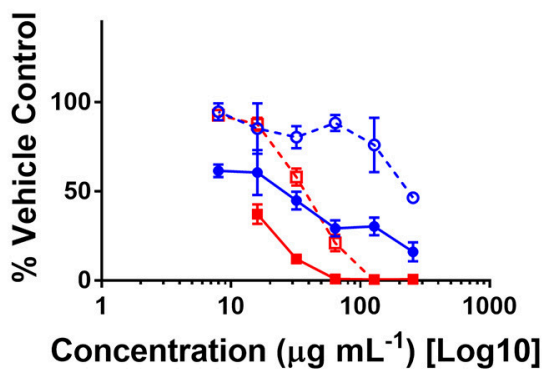

agr IV (AH1872)

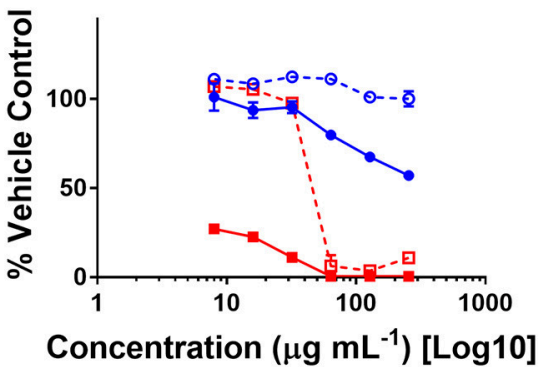

1290

\section{C-F2}

FIGURE 4 | Quorum quenching activity of extracts on S. aureus agr reporter strains. Extracts were screened against an agr I reporter strain of S. aureus (AH1677) at a concentration of $256 \mu \mathrm{g} \mathrm{mL}^{-1}$. Growth was measured by OD, and quorum sensing activity by FLD. Vehicle (water and DMSO) and positive extract (224C-F2) were included: (A) ethanolic extracts (B) aqueous extracts. Significance was determined in comparison to the vehicle control, with ${ }^{*} p<0.05$, ${ }^{* \star} p<0.01$, and ${ }^{* \star *} p<0.001$. (C) The active extract 1290 (Z. armatum EtOH fruit extract) was examined in dose response assays against agr I-IV reporters in comparison to the positive control (224C-F2), reported as \%FLD of vehicle control for solid lines and \%OD for growth in dashed lines. 
only extract to exhibit dose dependent inhibition of $A$. baumannii (CDC-33) and K. pneumoniae (EU-32) was M. annua, with an $\mathrm{IC}_{50}$ of $256 \mu \mathrm{g} \mathrm{mL}^{-1}$ (Figure 2). None of the extracts exhibited an MIC (>90\% inhibition) at the maximum concentration tested $\left(256 \mu \mathrm{g} \mathrm{mL}^{-1}\right)$.

\section{Extracts Exhibit Limited to No Biofilm Inhibitory Activity in S. aureus}

In our static microtiter plate crystal violet assay, modest biofilm inhibitory activity was noted among organic extracts when screened at $256 \mu \mathrm{g} \mathrm{mL} \mathrm{m}^{-1}$. The extracts had no major ( $>50 \%$ inhibition) impact on biofilm formation, with the exception of extract 1290 (Z. armatum) (Figure 3A). However, further analysis revealed that the observed anti-biofilm activity (Figure 3B) was due to overall growth inhibition at this dose (Figure 3C), rather than biofilm targeted activity.

\section{Extracts Exhibit Modest to High Quorum Quenching Activity in S. aureus}

Quorum quenching (QQ) activity was investigated using four reporter strains of $S$. aureus agr subtypes (agr I-IV). QQ activity was revealed by a screen of the extracts at $256 \mu \mathrm{g} \mathrm{mL}^{-1}$ in an agr I reporter strain. Modest, but statistically significant, inhibition of quorum sensing was observed in tests on B. lycium, S. chirata, N. oleander, G. olivieri, A. capillus-veneris, and A. absinthium ethanol extracts (Figure 4A). Similarly, modest and significant inhibition of quorum sensing was observed in some of the aqueous extracts, including for $Z$. armatum, B, lyceum, $S$. chirata, N. oleander and A. absinthium (Figure 4B). Neither the ethanolic or aqueous extracts of $P$. pashia or $M$. annua exhibited any quorum quenching activity in the screen against agr I. The ethanolic extract of $Z$. armatum (1290), the most active extract, was subsequently tested against all four agr subtypes in a set of dose response experiments (Figure 4C). The extract inhibited quorum sensing in all four agr types at sub-MIC concentrations, and yielded an $\mathrm{IC}_{50}$ of 256,32 , and $256 \mu \mathrm{g} \mathrm{mL}^{-1}$ in agr types I, II and III, respectively. No IC $_{50}$ was reached for $\operatorname{agr}$ IV at the maximum concentration tested.

\section{Extract 1290 Blocks Production of Virulence Factor $\delta$-toxin in S. aureus}

To confirm the quorum sensing inhibitory activity of extract 1290 observed in the reporter model (Figure 4), we assessed its ability to inhibit $\delta$-toxin production at concentrations of 64 and $256 \mu \mathrm{g}$ $\mathrm{mL}^{-1}$. To this end, six strains of $S$. aureus known to be high-level producers of $\delta$-toxin were grown with extract 1290 or vehicle, and the cell supernatant harvested for analysis by HPLC. The extract significantly inhibited toxin production at doses of 64 and $256 \mu \mathrm{g}$ $\mathrm{mL}^{-1}$ against two and six of the six strains studied, respectively (Figure 5).

\section{Extracts Are Nontoxic to Human Keratinocytes}

Human skin keratinocytes (HaCaTs) were exposed to the aqueous and organic extracts to assess potential cytotoxic effects on mammalian cells. All extracts were well tolerated by the cell line when tested at a screening concentration of $100 \mu \mathrm{g} \mathrm{mL}-1$ (Figure 6A). Due to its activity in antibacterial assays, extract 1290 was further examined in a dose-response study at a range of 8-1, $024 \mu \mathrm{g} \mathrm{mL}^{-1}$, and was found to exhibit slight toxicity over the vehicle control at the highest doses of 512 and $1,024 \mu \mathrm{g} \mathrm{mL}^{-1}$, but no $\mathrm{IC}_{50}$ was reached at these concentrations (Figure 6B).

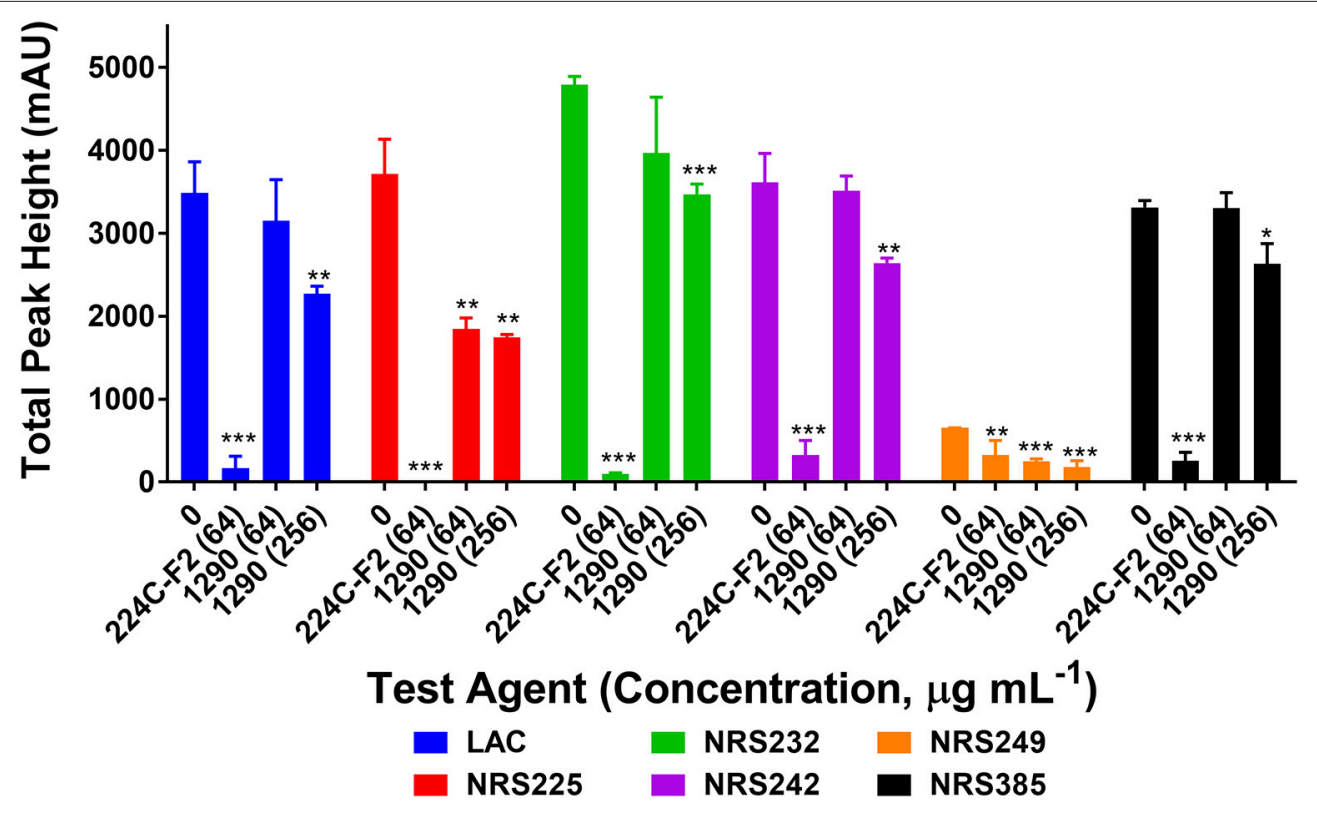

FIGURE 5 | Impact of the ethanolic extract of Zanthoxylum armatum fruits on $\delta$-toxin production (measured by HPLC) in six strains of hypervirulent Staphylococcus aureus (Table 2). Significance was determined in comparison to the vehicle control (DMSO), with ${ }^{*} p<0.05$, ${ }^{* *} p<0.01$, and ${ }^{\star \star *} p<0.001$. $224 \mathrm{C}-\mathrm{F} 2$, a bioactive fraction of Castanea sativa leaf extract (Quave et al., 2015), was used as a positive control (tested at $64 \mu \mathrm{g} \mathrm{mL}{ }^{-1}$ ). 


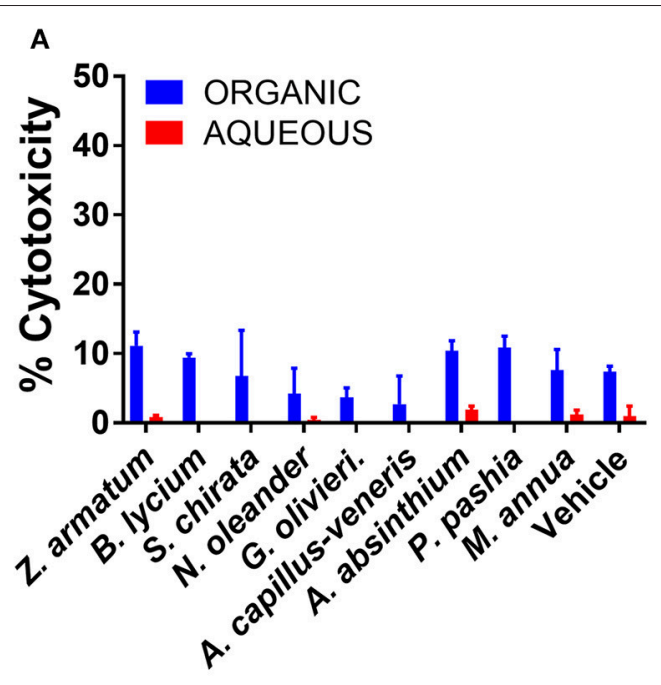

Test Agent $\left(100 \mu \mathrm{g} \mathrm{mL}^{-1}\right)$

B

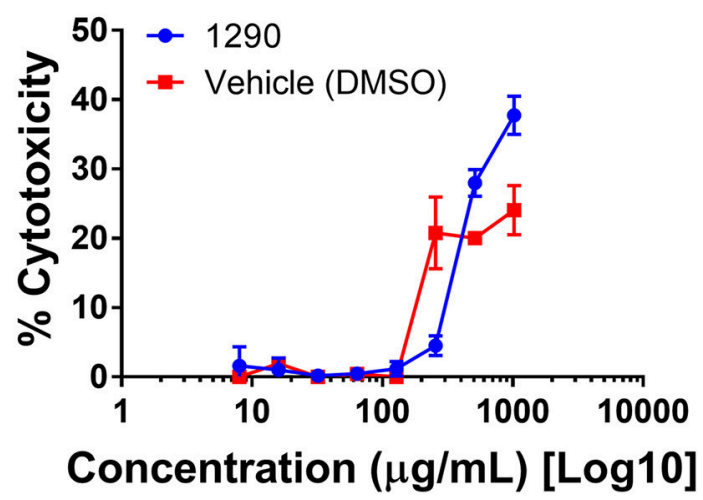

FIGURE 6 | Cytotoxicity of extracts in a human keratinocyte (HaCaT) cell line by LDH assay for cell viability. (A) Organic and aqueous extracts were screened at $100 \mu \mathrm{g} \mathrm{mL}^{-1}$. Significance was determined in comparison to the vehicle control (DMSO), with ${ }^{\star} p<0.05,{ }^{* *} p<0.01$, and ${ }^{* * *} p<0.001$. (B) Extract 1290 was examined by dose response study from 8 to $1,024 \mu \mathrm{g}$ $\mathrm{mL}^{-1}$.

\section{Chemical Characterization of Active Extracts}

Ethanol extracts of Zanthoxylum armatum (1290), Adiantum capillus-veneris (1294), and Artemisia absinthium (1308) were assessed by HPLC (Figure 7). As the most promising bioactive extract, Z. armatum was selected for further analysis by LCFTMS, which revealed the presence of 29 major compounds with relative abundance $>1 \%$. Putative matches based on isotopic analysis and database searches were possible for 8 of these: (1) threo-3-methoxy-5-hydroxy-phenylpropanetriol-8-O- $\beta$-Dglucopyranoside, (4) 3-[[6-O-(6-deoxy- $\alpha$-L-mannopyranosyl)$\beta$-D-glucopyranosyl]oxy]-2-(3,4-dihydroxyphenyl)-5,7-

dihydroxy-4H-1-benzopyran-4-one, (9) 6'-methoxy-( $8 \alpha, 9 \mathrm{R})$ cinchonan-9-ol, (15) N-(2,3-dihydroxy-2-methylpropyl)2,6,8,10-dodecatetraenamide, (21) 3,5,7-trihydroxy-8methoxy-2-(4-methoxyphenyl)-4H-1-benzopyran-4-one,

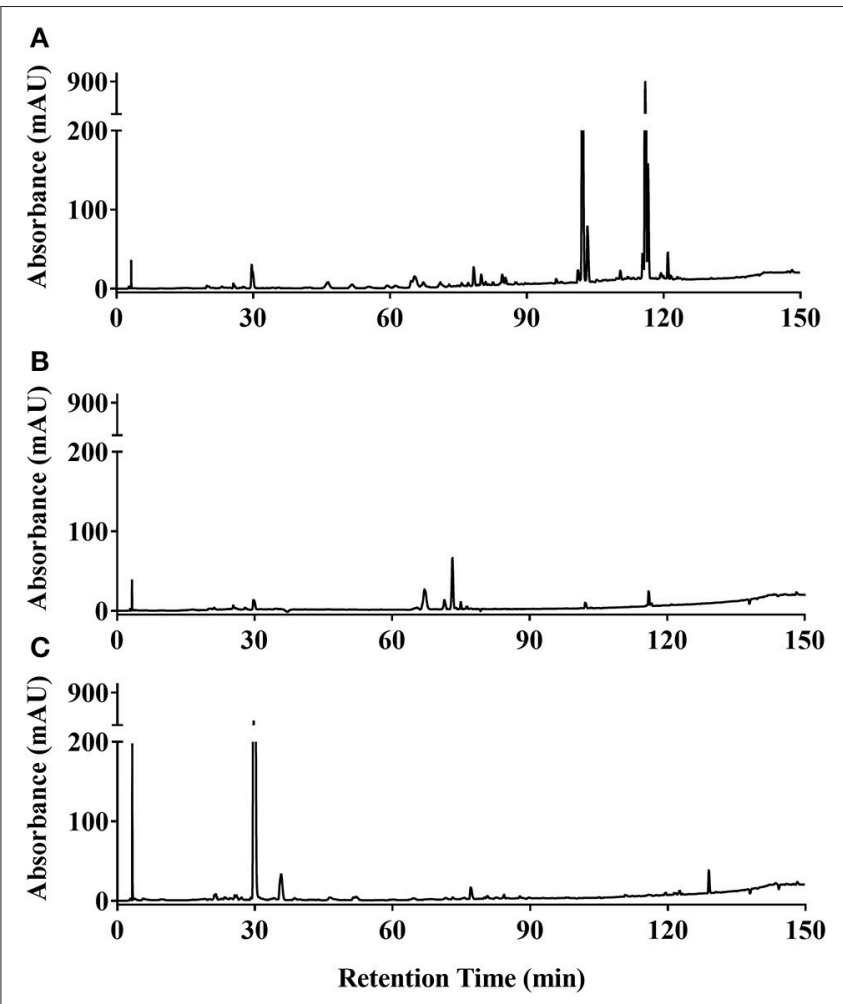

FIGURE 7 | HPLC chromatograms at $254 \mathrm{~nm}$ of ethanolic extracts of (A) Zanthoxylum armatum fruits (1290); (B) Adiantum capillus-veneris whole plant (1,294); and (C) Artemisia absinthium aerial parts (1,308).

(24) N-(2-methylpropyl)-2,6,8,10-dodecatetraenamide, $\mathrm{N}$-(2-methylpropyl)-2,4,8,10,12-tetradecapentaenamide, 9,12,15-octadecatrienoic acid (Figure 8, Table 4).

\section{DISCUSSION}

The aim of this study was to examine extracts of plants selected based on traditional medicinal use for growth inhibitory, biofilm inhibitory, cytotoxicity, and quorum quenching activity in a series of in vitro assays. We selected a panel of clinically-relevant, multidrug-resistant human pathogens for these studies. All of the selected medicinal species exhibited some degree of anti-infective activity in our models, with the exception of Pyrus pashia. It is important to note that this does not rule out the potential efficacy of $P$. pashia in traditional medicine, where it is used as a laxative and for gastrointestinal disorders (Janbaz et al., 2015), as we did not specifically target laboratory models for these functions beyond inclusion of select gut pathogens, and are limited by exclusion of host-directed studies.

With regards to growth inhibition, it is not unexpected to see poor to no activity among extracts against the Gram-negative species tested. The presence of the outer membrane, which is difficult to penetrate, as well as constitutively overexpressed efflux pumps, make these pathogens much more difficult to target with antibiotics or herbal extracts than Gram-positive 


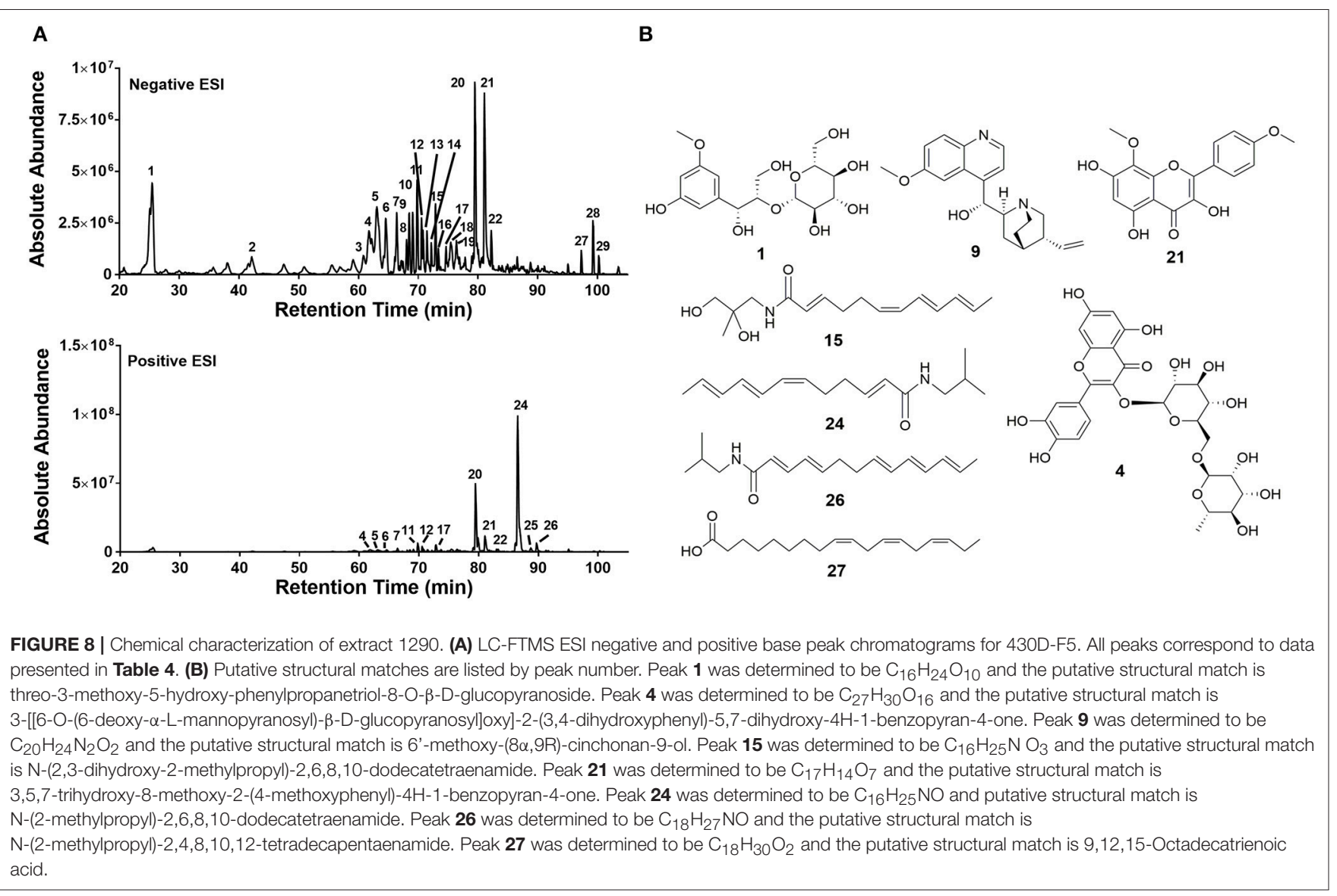

pathogens (Domalaon et al., 2018). Of the extracts evaluated, four exhibited activity against a Gram-positive pathogen, while the ethanolic extract of Martynia annua fruits (Extract 1310) was the only one to exhibit some activity against both Gram-positive and Gram-negative pathogens (Table 3 ). While the activity was modest ( $\mathrm{IC}_{50}$ of $256 \mu \mathrm{g} \mathrm{mL}^{-1}$ ) against Acinetobacter baumannii, Enterococcus faecium, Klebsiella pneumoniae and Staphylococcus aureus, it is still worth further examination as the active consituent(s) may represent a small portion of the chemically complex crude extract. We recommend further studies focused on the bioassay-guided fractionation of this extract to determine if a refined fraction or isolated compound(s) can achieve an MIC at a therapeutically relevant concentration. The current literature on $M$. annua is focused on its efficacy in wound healing. To that end, studies demonstrate the efficacy of a $5 \% \mathrm{w} / \mathrm{w}$ ointment of M. апnиa methanolic fractions in dead space and burn wound models (Lodhi et al., 2016), a 0.5\% w/w ointment flavonoid enriched fraction on healing in an in vivo diabetic wound model (Lodhi and Singhai, 2013), and fractions of ethanolic leaf extracts in rat excision and incision models (Santram and Singhai, 2011). To the best of our knowledge, this is the first report of antibacterial activity of this $M$. annua against ESKAPE pathogens.

Other species exhibiting dose-dependent growth inhibitory activity against $S$. aureus and E. faecium included Zanthoxylum armatum, Artemisia absinthium, and Adiantum capillus-veneris (Figure 2). A prior study on the antibacterial activity of $Z$. armatum extracts determined by disc diffusion and broth microtiter dilution methods reported MICs at very high doses, ranging from 10,000 to $200,000 \mu \mathrm{g} \mathrm{mL}^{-1}$, for a panel of 11 bacterial pathogens (Wazir et al., 2014). Other prior studies on the antibacterial activity of $Z$. armatum were restricted to disc diffusion assays and this methodology presents limitations in the comparison of one extract to another, and the establishment of $\mathrm{IC}_{50}$ or MIC values. However, disc diffusion results can be informative as a basic starting point to identifying species with potential antibacterial activity. In one study, the activity of an ethanolic extract of fruits was reported against a strain of S. aureus and Salmonella typhi (Hussain et al., 2017). In another study, the methanolic fraction of the fruits exhibited some activity when loaded at a dose of $500 \mu \mathrm{g} \mathrm{disc}{ }^{-1}$ against S. aureus, Streptococcus mutans, P. aeruginosa, Salmonella typhi, Enterococcus faecalis, Bacillus subtilis, Staphylococcus epidermidis, and Streptococcus pyogenes (Nooreen et al., 2017). The antifungal activity of the fruit extract has also been reported, with the most activity demonstrated against Trichophyton longifusis at $200 \mu \mathrm{g}$ $\mathrm{mL}^{-1}$ by agar dilution method (Alam and us Saqib, 2017).

The antibacterial activity of Adiantum capillus-veneris has been previously reported based on disc diffusion assays, with some activity noted against Escherichia coli, Staphylococcus 
TABLE 4 | Negative and positive ESI Mass spectrometry $(\mathrm{m} / \mathrm{z})$ analysis of extract 1290; peaks with > 1\% relative abundance are listed.

\begin{tabular}{|c|c|c|c|c|c|c|c|c|}
\hline \multirow[t]{2}{*}{ Peak \# } & \multirow{2}{*}{$\begin{array}{l}\text { RT } \\
(\min )\end{array}$} & \multicolumn{2}{|c|}{ (\%) Relative abundance } & \multirow{2}{*}{$\begin{array}{c}\text { Formula }(\Delta \\
- \text { ppm })^{\mathrm{a}}\end{array}$} & \multirow[t]{2}{*}{ Putative compounds } & \multirow[t]{2}{*}{ ESI Mode } & \multirow[t]{2}{*}{$m / z^{b}$} & \multirow[t]{2}{*}{ MS $^{2}$} \\
\hline & & Neg.N & Pos.Mode & & & & & \\
\hline 2 & 42.14 & 2.48 & 0.49 & $\mathrm{C}_{14} \mathrm{H}_{28} \mathrm{O}_{9}(2.9)$ & no matches & - & $\begin{array}{l}\mathbf{3 4 0 . 1 7 6 8 7} \\
408.16466\end{array}$ & $\begin{array}{l}294.03311 \\
276.07231\end{array}$ \\
\hline 4 & 61.75 & 5.79 & 1.59 & $\mathrm{C}_{27} \mathrm{H}_{30} \mathrm{O}_{16}$ (1.4) & $\begin{array}{c}\text { 3-[[6-O-(6-deoxy- } \alpha-\mathrm{L}- \\
\text { mannopyranosyl)- } \beta \text {-D- } \\
\text { glucopyranosyl] } 0 x y]-2-(3,4- \\
\text { dihydroxyphenyl)-5,7-dihydroxy-4H- } \\
\text { 1-benzopyran-4-one }\end{array}$ & - & $\begin{array}{l}\text { 609.14745 } \\
499.08701\end{array}$ & $\begin{array}{l}300.91790, \\
299.92698\end{array}$ \\
\hline 7 & 66.39 & 3.29 & 1.34 & $\mathrm{C}_{21} \mathrm{H}_{19} \mathrm{O}_{11}$ (0.8) & no matches & - & $\begin{array}{c}\text { 447.09409, } \\
593.1531\end{array}$ & $\begin{array}{l}283.92544, \\
327.00141\end{array}$ \\
\hline 8 & 68.05 & 1.17 & 0.29 & $\mathrm{C}_{24} \mathrm{H}_{21} \mathrm{O}_{14}(1.0)$ & no matches & - & $\begin{array}{l}\mathbf{5 3 3 . 0 9 4 8 1} \\
601.08393\end{array}$ & 489.04098 \\
\hline 9 & 68.49 & 2.26 & 0.47 & $\begin{array}{c}\mathrm{C}_{20} \mathrm{H}_{24} \mathrm{~N}_{2} \mathrm{O}_{2} \\
(-2.0)\end{array}$ & $6^{\prime}$-methoxy-(8a,9R)-cinchonan-9-ol & - & $\begin{array}{l}\mathbf{3 2 6 . 1 9 7 9 3} \\
607.39844\end{array}$ & $\begin{array}{l}280.04288, \\
236.09022\end{array}$ \\
\hline 10 & 69.07 & 2.12 & - & $\mathrm{C}_{38} \mathrm{H}_{55} \mathrm{O}_{6}(-1.9)$ & no matches & - & $\begin{array}{l}\mathbf{6 0 7 . 3 9 8 4 4} \\
394.18629\end{array}$ & $\begin{array}{l}298.97899, \\
561.12814\end{array}$ \\
\hline 11 & 69.79 & 3.75 & 1.84 & $\begin{array}{c}\mathrm{C}_{20} \mathrm{H}_{24} \mathrm{~N}_{2} \mathrm{O}_{2} \\
(-1.9)\end{array}$ & no matches & - & $\begin{array}{l}\mathbf{3 2 4 . 1 8 2 3} \\
603.36732\end{array}$ & $\begin{array}{l}278.00556 \\
220.01256\end{array}$ \\
\hline 12 & 70.53 & 3.03 & 1.48 & $\mathrm{C}_{17} \mathrm{H}_{28} \mathrm{O}_{10}$ (4.0) & no matches & - & $\begin{array}{l}\text { 392.17037, } \\
603.36731\end{array}$ & $\begin{array}{l}278.00556, \\
324.21714\end{array}$ \\
\hline 17 & 74.67 & 0.91 & 0.29 & $\mathrm{C}_{18} \mathrm{H}_{33} \mathrm{O}_{5}(0.3)$ & no matches & - & $\begin{array}{c}\mathbf{3 2 9 . 2 3 3 7 5} \\
621.3777\end{array}$ & $\begin{array}{l}229.0025 \\
211.03004\end{array}$ \\
\hline 18 & 75.44 & 2.26 & - & $\mathrm{C}_{38} \mathrm{H}_{53} \mathrm{O}_{7}(-2.7)$ & no matches & - & $\begin{array}{l}\text { 621.37695, } \\
689.36582\end{array}$ & $\begin{array}{l}575.01788, \\
296.03969\end{array}$ \\
\hline 19 & 76.39 & 1.9 & 1.25 & $\mathrm{C}_{38} \mathrm{H}_{53} \mathrm{O}_{7}(-2.9)$ & no matches & - & $\begin{array}{l}621.37677 \\
689.36591\end{array}$ & $\begin{array}{l}575.01788, \\
296.03969\end{array}$ \\
\hline 20 & 79.46 & 9.96 & 14.01 & $\mathrm{C}_{14} \mathrm{H}_{28} \mathrm{O}_{7}$ (3.2) & no matches & - & $\begin{array}{l}\mathbf{3 0 8 . 1 8 7 2 8} \\
605.38301\end{array}$ & $\begin{array}{l}262.06560, \\
290.08820\end{array}$ \\
\hline 21 & 81.05 & - & 4.65 & $\mathrm{C}_{17} \mathrm{H}_{14} \mathrm{O}_{7}(-0.7)$ & $\begin{array}{c}\text { 3,5,7-trihydroxy-8-methoxy-2-(4- } \\
\text { methoxyphenyl)-4H-1-benzopyran-4- } \\
\text { one }\end{array}$ & + & $\begin{array}{l}\mathbf{3 3 1 . 0 8 1 0 7} \\
280.19090\end{array}$ & 316.04065 \\
\hline 22 & 82.21 & 1.18 & - & $\mathrm{C}_{25} \mathrm{H}_{29} \mathrm{O}_{8}(0.6)$ & no matches & - & $\begin{array}{l}\mathbf{4 5 7 . 1 8 7 5 2} \\
411.18216\end{array}$ & $\begin{array}{l}411.05709, \\
389.12406\end{array}$ \\
\hline 23 & 83.23 & - & 0.91 & $\mathrm{C}_{21} \mathrm{H}_{21} \mathrm{O}_{5}(-0.1)$ & no matches & + & $\begin{array}{l}\text { 353.13831 } \\
741.29147\end{array}$ & $\begin{array}{l}322.00452 \\
190.94986\end{array}$ \\
\hline 24 & 86.53 & - & 41.32 & $\mathrm{C}_{16} \mathrm{H}_{25} \mathrm{NO}(-0.1)$ & $\begin{array}{l}\mathrm{N} \text {-(2-methylpropyl)-2,6,8,10- } \\
\text { dodecatetraenamide }\end{array}$ & + & $\begin{array}{l}\text { 495.39285, } \\
\mathbf{2 4 8 . 2 0 0 7 7}\end{array}$ & $\begin{array}{l}149.09491 \\
174.90641\end{array}$ \\
\hline 25 & 88.74 & - & 1.12 & $\mathrm{C}_{30} \mathrm{H}_{57} \mathrm{O}_{8}(2.7)$ & no matches & + & $\begin{array}{l}\mathbf{5 4 5 . 4 0 8 1 4} \\
361.32182\end{array}$ & $\begin{array}{l}527.25299 \\
284.11325\end{array}$ \\
\hline
\end{tabular}




\begin{tabular}{|c|c|c|c|c|c|c|c|c|}
\hline \multirow[t]{2}{*}{ Peak \# } & \multirow{2}{*}{$\underset{(\min )}{\mathrm{RT}}$} & \multicolumn{2}{|c|}{ (\%) Relative abundance } & \multirow{2}{*}{$\begin{array}{c}\text { Formula }(\Delta \\
- \text { ppm) }\end{array}$} & \multirow[t]{2}{*}{ Putative compounds } & \multirow[t]{2}{*}{ ESI Mode } & \multirow[t]{2}{*}{$m / z^{b}$} & \multirow[t]{2}{*}{ MS $^{2}$} \\
\hline & & Neg. & Pos.Mode & & & & & \\
\hline 26 & 89.7 & - & 2.23 & $\mathrm{C}_{18} \mathrm{H}_{27} \mathrm{NO}(0.05)$ & $\begin{array}{l}\text { N-(2-methylpropyl)-2,4,8,10,12- } \\
\text { tetradecapentaenamide }\end{array}$ & + & $\begin{array}{l}\mathbf{2 7 4 . 2 1 6 5 9} \\
373.32187\end{array}$ & $\begin{array}{l}174.98173, \\
132.92981\end{array}$ \\
\hline 27 & 97.29 & 0.7 & - & $\mathrm{C}_{18} \mathrm{H}_{30} \mathrm{O}_{2}(0.2)$ & 9,12,15-Octadecatrienoic acid & - & $\begin{array}{l}555.44309 \\
277.21756\end{array}$ & $\begin{array}{l}233.1687 \\
259.12869\end{array}$ \\
\hline 28 & 99.23 & 1.79 & 0.29 & $\mathrm{C}_{17} \mathrm{H}_{31} \mathrm{O}_{4}(0.5)$ & no matches & - & $\begin{array}{l}\mathbf{5 0 7 . 4 4 3 3 6} \\
299.22334\end{array}$ & $\begin{array}{l}445.27496, \\
283.91006\end{array}$ \\
\hline 29 & 100.2 & 0.52 & 0.28 & $\mathrm{C}_{36} \mathrm{H}_{63} \mathrm{O}_{4}(1.2)$ & no matches & - & $\begin{array}{l}\mathbf{5 5 9 . 4 7 4 4 7} \\
497.34979\end{array}$ & $\begin{array}{l}321.05199, \\
255.13572\end{array}$ \\
\hline
\end{tabular}

The corresponding chromatograms for negative and positive ESI are reported in Figure $\mathbf{8 A}$, with putative structural matches reported in Figure $\mathbf{8 B}$.

a The empirical formula corresponds to the $[\mathrm{M}+\mathrm{H}]^{+}$or $[\mathrm{M}-\mathrm{H}]^{-}$ion as determined by the ionization mode.

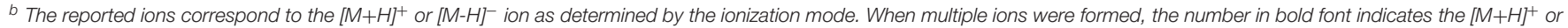
$[\mathrm{M}-\mathrm{H}]^{-}$and underwent $\mathrm{MS}^{2}$ analysis.

aureus, and Klebsiella pneumoniae, but no MICs or mammalian cytotoxicity counter screen data is available (Ishaq et al., 2014). Likewise, the antibacterial activity of Artemisia absinthium has been broadly reported against a number of pathogens, including Pseudomonas aeruginosa and Staphylococcus aureus, see for example (Kordali et al., 2005; Valdés et al., 2008; Fiamegos et al., 2011; Moslemi et al., 2012).

Although none of the extracts inhibited biofilm formation in S. aureus at concentrations sub-inhibitory for growth (Figure 3), we did note significant $S$. aureus quorum quenching activity in all of the extracts tested, with the exception of the ethanolic extracts of $P$. pashia and M. annua (Figure 4A) and the aqueous extracts of G. olivieri, P. pashia, and M. annua (Figure 4B) in a S. aureus agr I reporter strain. Of all the extracts, $Z$. armatum exhibited the greatest potential for quorum quenching across all four agr types (Figure 4C), and this is the first report of its quorum quenching potential. In $S$. aureus, quorum sensing via a two component signaling system is the chief mediator of virulence, which includes the production of toxins that exert lytic activity on a number of human cell types (Grumann et al., 2014; Salam and Quave, 2018). Of these, $\delta$-toxin production has been indicated as a very accurate measure of quorum sensing activity and bacterial virulence in general (Quave and Horswill, 2018). The $\delta$-toxin gene, $h l d$, is coded by RNAIII, the expression of which is directly regulated by quorum sensing (Benito et al., 2000). In addition to noting activity in $a g r$ fluorescent reporters, we also demonstrated the reduction in overall $\delta$-toxin production by HPLC analysis following treatment of six S. aureus strains with extract 1290 of Z. armatum (Figure 5).

Our studies on $Z$. armatum fruit extract (1290) exhibited no substantial cytotoxicity ( no $\mathrm{IC}_{50}$ ) at our maximum concentration tested $\left(1,024 \mu \mathrm{g} \mathrm{mL}^{-1}\right.$, Figure 6B), suggesting that use of this species is safe to human cells. Although the virulence assays were performed only on $S$. aureus strains in this study, further research on virulence mechanisms in other ESKAPE pathogens is merited. Furthermore, bioassay-guided fractionation of the extractwhich exhibited significant, but modest, quorum quenching activity in S. aureus - could lead to improved activity with further refinement of the extract or isolation of active constituent(s).

\section{CONCLUSION}

Our work has demonstrated the anti-infective potential of extracts from some selected Pakistani medicinal plants. Of the nine species tested, five exhibited some level of antibacterial activity in our growth inhibition model, none in staphylococcal biofilm inhibition, and seven in the $S$. aureus quorum quenching model. We suggest that future studies on the anti-infective potential of these medicinal plants also address the anti-biofilm and quorum quenching activity of the other ESKAPE pathogens, pending the development of appropriate control strains and reporter model systems.

Of greatest note for growth inhibitory studies, the fruit of Martynia annua, which is used in traditional medicine for skin infections and sore throat, exhibited the most broad-spectrum growth inhibitory activity against ESKAPE pathogens, including MDR strains of Acinetobacter baumannii, Enterococcus faecium, Klebsiella pneumoniae, and Staphylococcus aureus in an ethanol extract (1310). However, this growth inhibitory activity was modest, with an $\mathrm{IC}_{50}$ of $256 \mu \mathrm{g} \mathrm{mL} \mathrm{m}^{-1}$, and no MIC was determined at the maximum concentration tested. On the other hand, the fruit of Zanthoxylum armatum, which is used in traditional medicine to treat infectious diseases of the gut and oral cavity, demonstrated the most promising activity in terms of reducing staphylococcal virulence $\left(\mathrm{IC}_{50} 32-256 \mu \mathrm{g} \mathrm{mL}^{-1}\right.$ ), as well as growth inhibition of the enteric pathogen Enterococcus faecium in an ethanol extract (1290). Chemical characterization of this extract revealed the presence of 29 major compounds, with putative matches for eight of these. The activity profile combined with absence of cytotoxicity $\left(\mathrm{IC}_{50}>1,024 \mu \mathrm{g} \mathrm{mL}^{-1}\right.$ ) suggests both the presence of promising compounds for the potential development of anti-virulence approaches as well as validation of this traditional therapy for management of certain infectious diseases.

\section{AUTHOR CONTRIBUTIONS}

MK collected the plant specimens, prepared extracts and performed the antibacterial and cell culture experiments. RP 
performed the biofilm experiments. MK, JL, and HT performed the chemical analysis of active extracts. HT performed $\delta$-toxin analyses. CQ and ZM designed and directed the study. MK and $\mathrm{CQ}$ analyzed the data and wrote the manuscript. All authors read, revised and approved the final manuscript.

\section{FUNDING}

This work was supported by a grant from the Higher education commission, government of Pakistan under international research support initiative program (IRSIP), award no:18/HEC/HRD/2017/7323. The work was also supported by a grant from the National Institutes of Health, National Center for Complementary and Integrative Health (R01 AT007052, PI: CQ). The content is solely the responsibility of the authors and does not necessarily reflect the official views of NCCIH or NIH. The funding agency had no role in study design, data collection and analysis, decision to publish, or preparation of the manuscript.

\section{ACKNOWLEDGMENTS}

The following reagents were obtained through BEI Resources, NIAID, NIH as part of the Human Microbiome Project:

\section{REFERENCES}

Abbasi, A. M., Khan, M. A., Ahmed, M., and Zafar, M. (2010). Herbal medicines used to cure various ailments by the inhabitants of Abbottabad district, North West Frontier Province, Pakistan. Indian J. Tradit. Knowl. 9, 175-183.

Abbasi, A. M., Khan, M. A., Khan, N., and Shah, M. H. (2013). Ethnobotanical survey of medicinally important wild edible fruits species used by tribal communities of lesser HimalayasPakistan. J. Ethnopharmacol. 148, 528-536. doi: 10.1016/j.jep.2013.0 4.050

Ahmad, I., and Beg, A. Z. (2001). Antimicrobial and phytochemical studies on 45 Indian medicinal plants against multi-drug resistant human pathogens. J. Ethnopharmacol. 74, 113-123. doi: 10.1016/S0378-8741(00)00 $335-4$

Ahmad, M., Sultana, S., Fazl-i-Hadi, S., Ben Hadda, T., Rashid, S., Zafar, M., et al. (2014). An ethnobotanical study of medicinal plants in high mountainous region of Chail valley (District Swat-Pakistan). J. Ethnobiol. Ethnomed. 10, 36. doi: 10.1186/1746-4269-10-36

Alam, F., and Us Saqib, Q. N. (2017). Evaluation of Zanthoxylum armatum Roxb for in vitro biological activities. J. Tradit. Complement. Med. 7, 515-518. doi: 10.1016/j.jtcme.2017.01.006

Ali, H., and Qaiser, M. (2009). The ethnobotany of Chitral valley, Pakistan with particular reference to medicinal plants. Pak. J. Bot. 41, 2009-2041.

Ali, H., Uddin, S., and Jalal, S. (2015). Chemistry and biological activities of Berberis lycium Royle. J. Biol. Active Prod. Nat. 5, 295-312. doi: 10.1080/22311866.2015.1073627

APG (2016). An update of the angiosperm phylogeny group classification for the orders and families of flowering plants: APG IV. Bot. J. Linn. Soc. 181, 1-20. doi: 10.1111/boj.12385

Bano, A., Ahmad, M., Hadda, T., Saboor, A., Sultana, S., Zafar, M., et al. (2014). Quantitative ethnomedicinal study of plants used in the skardu valley at high altitude of Karakoram-Himalayan range, Pakistan. J. Ethnobiol. Ethnomed. 10:43. doi: 10.1186/1746-4269-10-43

Beenken, K. E., Blevins, J. S., and Smeltzer, M. S. (2003). Mutation of sarA in Staphylococcus aureus limits biofilm formation. Infect. Immun. 71, 4206-4211. doi: 10.1128/IAI.71.7.4206-4211.2003
Enterococcus faecium, Strain 513, HM-959; Enterococcus faecium, Strain E0164, NR-31915. The following reagents were obtained through BEI Resources, NIAID, NIH: Klebsiella pneumoniae, Isolate 1, NR-15410; Acinetobacter baumannii, Strain Naval-81, NR-17786. The following reagents were provided by the Network on Antimicrobial Resistance in Staphylococcus aureus (NARSA) for distribution by BEI Resources, NIAID, NIH: Staphylococcus aureus, Strain 95938, NR-46071, NRS385; Strain HT20020341, NR-46042, NRS249; Strain HT20020320; NR-46038, NRS245; Strain HT20020238, NRS242; and Strain HT20020065, NRS232. The following reagents were obtained through the Centers for Disease Control Antibiotic/Antimicrobial Resistance Bank: Acinetobacter baumannii, AR-BANK \#0033; Enterobacter cloacae, AR-BANK \#0032; Klebsiella pneumoniae, AR-BANK \#0076, Pseudomonas aeruginosa, AR-BANK \#0054. Thanks to Alex Horswill (UC Denver) for provision of the Staphylococcus aureus agr reporter isolates: AH1677, AH430, AH1747, and AH1872. Thanks to Akram Salam and Brandon Dale (Emory University) for assistance in the lab and critical review of the manuscript. Thanks to Dr. Rehmatullah Qureshi (PMAS-UAAR Pakistan) and Dr. Tharangamala Samarakoon (Emory University Herbarium) for their assistance with taxonomic confirmation of the collected species.

Benito, Y., Kolb, F. A., Romby, P., Lina, G., Etienne, J., and Vandenesch, F. (2000). Probing the structure of RNAIII, the Staphylococcus aureus agr regulatory RNA, and identification of the RNA domain involved in repression of protein A expression. RNA 6, 668-679. doi: 10.1017/S1355838200992550

Bhatt, V., Sharma, S., Kumar, N., Sharma, U., and Singh, B. (2017). Simultaneous quantification and identification of flavonoids, lignans, coumarin and amides in leaves of Zanthoxylum armatum using UPLC-DAD-ESI-QTOF-MS/MS J. Pharm. Biomed. Anal. 132, 46-55. doi: 10.1016/j.jpba.2016.09.035

Bibi, Y., Nisa, S., Chaudhary, F. M., and Zia, M. (2011). Antibacterial activity of some selected medicinal plants of Pakistan. BMC Complement. Altern. Med. 11, 52. doi: 10.1186/1472-6882-11-52

Boucher, H. W., Talbot, G. H., Bradley, J. S., Edwards, J. E., Gilbert, D., Rice, L. B., et al. (2009). Bad Bugs, No Drugs: No ESKAPE! an update from the infectious diseases society of america. Clin. Infect. Dis. 48, 1-12. doi: 10.1086/595011

Cioch, M., Satora, P., Skotniczny, M., Semik-Szczurak, D., and Tarko, T. (2017). Characterisation of antimicrobial properties of extracts of selected medicinal plants. Pol. J. Microbiol. 66, 463-472. doi: 10.5604/01.3001.0010.7002

CLSI (2013). "M100-S23," in Performance Standards for Antimicrobial Testing; 23rd Informational Supplement. Wayne, PA: Clinical and Laboratory Standards Institute.

Cowan, M. M. (1999). Plant products as antimicrobial agents. Clin. Microbiol. Rev. $12,564-582$.

Dhingra, A. K., Chopra, B., and Mittal, S. K. (2013). Martynia annua L.: a review on Its ethnobotany, phytochemical and pharmacological profile. J. Pharmacogn. Phytochem. 1, 135-140.

Domalaon, R., Idowu, T., Zhanel, G. G., and Schweizer, F. (2018). Antibiotic hybrids: the next generation of agents and adjuvants against Gram-Negative pathogens? Clin. Microbiol. Rev. 31:e00077-17 . doi: 10.1128/CMR.00077-17

Fiamegos, Y. C., Kastritis, P. L., Exarchou, V., Han, H., Bonvin, A. M., Vervoort, J., et al. (2011). Antimicrobial and efflux pump inhibitory activity of caffeoylquinic acids from Artemisia absinthium against Gram-positive pathogenic bacteria. PLoS ONE 6:e18127. doi: 10.1371/journal.pone.0018127

Fluck, H., and Jaspersen Schib, R. (1941). Medicinal Plants and Their Uses: Medicinal Plants, Simply Described and Illustrated With Notes on Their Constituents, Actions and Uses, Their Collection, Cultivation and Preparations. London: W. Foulsham, 188. 
Founou, R. C., Founou, L. L., and Essack, S. Y. (2017). Clinical and economic impact of antibiotic resistance in developing countries: a systematic review and meta-analysis. PLoS ONE 12:e0189621. doi: 10.1371/journal.pone.0189621

Grumann, D., Nübel, U., and Bröker, B. M. (2014). Staphylococcus aureus toxins-their functions and genetics. Infect. Genet. Evolut. 21, 583-592. doi: 10.1016/j.meegid.2013.03.013

Harborne, J. B., and Baxter, H. (1995). Phytochemical Dictionary: A Handbook of Bioactive Compounds from Plants. London: Taylor and Francis.

Harvey, A. L., Edrada-Ebel, R., and Quinn, R. J. (2015). The re-emergence of natural products for drug discovery in the genomics era. Nat. Rev. Drug Discov. 14, 111-129. doi: $10.1038 / \mathrm{nrd} 4510$

Hayat, M. Q., Khan, M. A., Ashraf, M., and Jabeen, S. (2009). Ethnobotany of the genus Artemisia, L. (Asteraceae) in Pakistan. Ethnobot. Res. Appl. 7, 147-162. doi: $10.17348 /$ era. $7.0 .147-162$

Hussain, M., and Gorsi, M. (2004). Antimicrobial activity of Nerium oleander Linn. Asian J. Plant Sci. 3, 177-180. doi: 10.3923/ajps.2004.177.180

Hussain, S., Murtaza, G., Mehmood, A., and Aleem Qureshi, R. (2017). Conservation of indigenous knowledge of medicinal plants of Western Himalayan region Rawalakot, Azad Kashmir, Pakistan. Pak. J. Pharm. Sci. 30, 773-782.

Ishaq, M. S., Hussain, M. M., Siddique Afridi, M., Ali, G., Khattak, M., Ahmad, S., et al. (2014). In vitro phytochemical, antibacterial, and antifungal activities of leaf, stem, and root extracts of Adiantum capillus veneris. Sci. World J. 2014:269793. doi: 10.1155/2014/2 69793

Janbaz, K. H., Zaeem Ahsan, M., Saqib, F., Imran, I., Zia-Ul-Haq, M., Abid Rashid, M., et al. (2015). Scientific basis for use of Pyrus pashia Buch.-Ham. ex D. Don. fruit in gastrointestinal, respiratory and cardiovascular ailments. PLoS ONE 10:e0118605. doi: 10.1371/journal.pone.01 18605

Khan, S. W., and Khatoon, S. (2008). Ethnobotanical studies on some useful herbs of Haramosh and Bugrote valleys in Gilgit, northern areas of Pakistan. Pak. J. Bot. 40, 43-58.

Kordali, S., Kotan, R., Mavi, A., Cakir, A., Ala, A., and Yildirim, A. (2005). Determination of the chemical composition and antioxidant activity of the essential oil of Artemisia dracunculus and of the antifungal and antibacterial activities of Turkish Artemisia absinthium, A. dracunculus, Artemisia santonicum, and Artemisia spicigera essential oils. J. Agric. Food Chem. 53, 9452-9458. doi: 10.1021/jf0516538

Kumar, V. P., Chauhan, N. S., Padh, H., and Rajani, M. (2006). Search for antibacterial and antifungal agents from selected Indian medicinal plants. J. Ethnopharmacol. 107, 182-188. doi: 10.1016/j.jep.2006.03.013

Kumar, V., and Van Staden, J. (2016). A review of Swertia chirayita (Gentianaceae) as a traditional medicinal plant. Front. Pharmacol. 6:308. doi: $10.3389 /$ fphar. 2015.00308

Lodhi, S., Jain, A., Jain, A. P., Pawar, R. S., and Singhai, A. K. (2016). Effects of flavonoids from Martynia annua and Tephrosia purpurea on cutaneous wound healing. Avicenna J. Phytomed. 6, 578-591.

Lodhi, S., and Singhai, A. K. (2013). Wound healing effect of flavonoid rich fraction and luteolin isolated from Martynia annua Linn. on streptozotocin induced diabetic rats. Asian Pac. J. Trop. Med. 6, 253-259. doi: 10.1016/S1995-7645(13)60053-X

Malik, T. A., Kamili, A. N., Chishti, M. Z., Ahad, S., Tantry, M. A., Hussain, P. R., et al. (2017). Breaking the resistance of Escherichia coli: antimicrobial activity of Berberis lycium royle. Microb. Pathog. 102, 12-20. doi: 10.1016/j.micpath.2016.11.011

Maroyi, A. (2013). Traditional use of medicinal plants in south-central Zimbabwe: review and perspectives. J. Ethnobiol. Ethnomed. 9:31. doi: 10.1186/1746-4269-9-31

Moslemi, H. R., Hoseinzadeh, H., Badouei, M. A., Kafshdouzan, K., and Fard, R. M. (2012). Antimicrobial activity of Artemisia absinthium against surgical wounds infected by Staphylococcus aureus in a rat model. Indian J. Microbiol. 52, 601-604. doi: 10.1007/s12088-012-0283-x

Muhs, A., Lyles, J. T., Parlet, C. P., Nelson, K., Kavanaugh, J. S., Horswill, A. R., et al. (2017). Virulence inhibitors from Brazilian Peppertree block quorum sensing and abate dermonecrosis in skin infection models. Sci. Rep. 4:42275. doi: $10.1038 /$ srep 42275
Nooreen, Z., Singh, S., Singh, D. K., Tandon, S., Ahmad, A., and Luqman, S. (2017). Characterization and evaluation of bioactive polyphenolic constituents from Zanthoxylum armatum DC., a traditionally used plant. Biomed. Pharmacother. 89, 366-375. doi: 10.1016/j.biopha.2017.02.040

O'Neill, J. (2016). Tackling Drug-Resistant Infections Globally: Final Report and Recommendations. Review on Antimicrobial Resistance.

Otto, M. (2004). Quorum-sensing control in Staphylococci - a target for antimicrobial drug therapy? FEMS Microbiol. Lett. 241, 135-141. doi: 10.1016/j.femsle.2004.11.016

Otto, M. (2014). Staphylococcus aureus toxins. Curr. Opin. Microbiol. 17, 32-37. doi: 10.1016/j.mib.2013.11.004

Pewtrusts.org. (2018). Tracking the Pipeline of Antibiotics in Development. Available online at: http://www.pewtrusts.org/en/research-and-analysis/ collections/2016/12/tracking-the-pipeline-of-antibiotics-in-development (Accessed April 15 2018).

Quave, C. L., Estévez-Carmona, M., Compadre, C. M., Hobby, G., Hendrickson, H., Beenken, K. E., et al. (2012). Ellagic acid derivatives from Rubus ulmifolius inhibit Staphylococcus aureus biofilm formation and improve response to antibiotics. PLOS ONE 7:e28737. doi: 10.1371/journal.pone.00 28737

Quave, C. L., and Horswill, A. R. (2014). Flipping the switch: tools for detecting small molecule inhibitors of staphylococcal virulence. Front. Microbiol. 5:706. doi: 10.3389/fmicb.2014. 00706

Quave, C. L., and Horswill, A. R. (2018). Identification of staphylococcal quorum sensing inhibitors by quantification of õ-hemolysin with high performance liquid chromatography. Methods Mol. Biol. 1673, 363-370. doi: 10.1007/978-1-4939-7309-5_27

Quave, C. L., Lyles, J. T., Kavanaugh, J. S., Nelson, K., Parlet, C. P., Crosby, H. A., et al. (2015). Castanea sativa (European Chestnut) leaf extracts rich in ursene and oleanene derivatives block Staphylococcus aureus virulence and pathogenesis without detectable rsesistance. PLOS ONE 10:e0136486. doi: 10.1371/journal.pone.0136486

Quave, C. L., Plano, L. R., Pantuso, T., and Bennett, B. C. (2008). Effects of extracts from Italian medicinal plants on planktonic growth, biofilm formation and adherence of methicillin-resistant Staphylococcus aureus. J. Ethnopharmacol. 118, 418-428. doi: 10.1016/j.jep.2008.0 5.005

Qureshi, R., Waheed, A., Arshad, M., and Umbreen, T. (2009). Medicoethnobotanical inventory of tehsil Chakwal, Pakistan. Pak. J. Bot. 41, 529-538.

Rossiter, S. E., Fletcher, M. H., and Wuest, W. M. (2017). Natural products as platforms to overcome antibiotic resistance. Chem. Rev. 117, 12415-12474. doi: 10.1021/acs.chemrev.7b00283

Salam, A. M., and Quave, C. L. (2018). Targeting virulence in Staphylococcus aureus by chemical inhibition of the accessory gene regulator system in vivo. $m$ Sphere 3, e00500-00517. doi: 10.1128/mSphere.00500-17

Santram, L., and Singhai, A. K. (2011). Preliminary pharmacological evaluation of Martynia annua Linn leaves for wound healing. Asian Pac. J. Trop. Biomed. 1, 421-427. doi: 10.1016/S2221-1691(11)60093-2

Schroeder, M., Brooks, B. D., and Brooks, A. E. (2017). The complex relationship between virulence and antibiotic resistance. Genes (Basel). 8:39. doi: $10.3390 /$ genes 8010039

Shaikh, B. T., and Hatcher, J. (2005). Complementary and alternative medicine in Pakistan: prospects and limitations. Evid. Based Complement. Alternat. Med. 2, 139-142. doi: 10.1093/ecam/neh088

Shinwari, Z. K. (2010). Medicinal plants research in Pakistan. J. Med. Plants Res. 4, $161-176$.

Thabit, A. K., Crandon, J. L., and Nicolau, D. P. (2015). Antimicrobial resistance: impact on clinical and economic outcomes and the need for new antimicrobials. Expert Opin. Pharmacother. 16, 159-177. doi: 10.1517/14656566.2015.993381

TPL (2017). The Plant List, Version 1.1. Available online at: http://www. theplantlist.org/ (Accessed December 21, 2017).

Valdés, A. F.-C., Mendiola Martínez, J., Scull Lizama, R., Vermeersch, M., Cos, P., and Maes, L. (2008). In vitro anti-microbial activity of the Cuban medicinal plants Simarouba glauca DC., Melaleuca leucadendron L. and Artemisia absinthium L. Mem. Inst. Oswaldo Cruz 103, 615-618. doi: 10.1590/S0074-02762008000600019 
Wazir, A., Mehjabeen, J. N., Sherwani, S., and Ahmad, M. (2014). Antibacterial, antifungal and antioxidant activities of some medicinal plants. Pak. J. Pharm. Sci. $27,2145-2152$.

WHO (2002). WHO Traditional Medicine Strategy 2002-2005. (Geneva, WHO).

WHO (2003). World Health Organization Guidelines on Good Agricultural and Collection Practices [GACP] for Medicinal Plants. Geneva: World Health Organization.

Wright, G. D. (2017). Opportunities for natural products in 21 st century antibiotic discovery. Nat. Prod. Rep. 34, 694-701. doi: 10.1039/C7NP00019G

Wu, H., Moser, C., Wang, H. Z., Høiby, N., and Song, Z. J. (2015). Strategies for combating bacterial biofilm infections. Int. J. Oral Sci. 7, 1-7. doi: 10.1038 /ijos.2014.65
Conflict of Interest Statement: The authors declare that the research was conducted in the absence of any commercial or financial relationships that could be construed as a potential conflict of interest.

Copyright () 2018 Khan, Tang, Lyles, Pineau, Mashwani and Quave. This is an open-access article distributed under the terms of the Creative Commons Attribution License (CC BY). The use, distribution or reproduction in other forums is permitted, provided the original author(s) and the copyright owner(s) are credited and that the original publication in this journal is cited, in accordance with accepted academic practice. No use, distribution or reproduction is permitted which does not comply with these terms. 